\title{
Avrupa İnsan Hakları Mahkemesi Kararları Işı̆̆ında Yabancılar ve Uluslararası Koruma Kanunu'nda Aralık 2019'da Yapılan Bazı Değişikliklerin Değerlendirilmesi
}

\author{
An Assessment of December 2019 Amendments to the Turkish Law on \\ Foreigners and International Protection in view of the European Court \\ of Human Rights Jurisprudence
}

\author{
Meltem İNELİ CİĞER ${ }^{*}$
}

Öz

6/12/2019 tarihli ve 7196 sayılı Bazı Kanunlarda ve 375 Sayılı Kanun Hükmünde Kararnamede Değişiklik yapılmasına Dair Kanun ile 6458 Sayılı Yabancilar ve Uluslararası Koruma Kanunu'nun (YUKK) bazı maddelerinde değişiklik yapılmış ve kanuna bazı ek maddeler getirilmiştir. Bu makalenin amacı Aralık 2019'da YUKK'da yapılan değişikliklerin Avrupa İnsan Hakları Sözleşmesi (AİHS) ile uygunluğunu Avrupa İnsan Hakları Mahkemesi (AİHM) kararları ışığında değerlendirmek ve söz konusu değişikliklerin uygulamasında insan hakları hukuku bakımından dikkat edilmesi gereken hususları ortaya koymaktır. Bu amaçla makalede YUKK m. 53(3)'de yapılan değişiklik ile sınır dışı kararlarına itiraz süresinin yedi güne indirilmesi hususu, sınır dışı kararlarına yapılan itirazların tüm yabancılar için yürütmeyi durdurma etkisi doğuracağına dair YUKK m. 53'te yapılan değişiklik ve Türkiye’ye girişlerine izin verilmeyecek yabancıların sınır kapılarında bekletilmesine ilişkin YUKK m. 7’de yapılan değişiklik AİHM içtihadı 1şı̆̆ında incelenmiştir. Makalede ayrıca, YUKK m. 57/A ile hukukumuza yeni getirilen idari gözetime alternatif yükümlülükler ve idari gözetim altına alınan yabancıların elektronik ve iletişim cihazlarının incelenebileceğine ilişkin YUKK m. 57'de yapılan değişiklik de değerlendirilmiştir.

Anahtar Kelimeler: AİHS m. 3 - AİHS m. 5 - AİHS m. 8 - YUKK Aralık 2019 değişiklikleri - İdari gözetime alternatif yükümlülükler - Sınır dışı kararlarına itiraz

\begin{abstract}
The Turkish Law on Foreigners and International Protection (Law No 7196) has been amended with the adoption of Law no 7196 on 6 December 2019. The aim of the article is to analyse the extent to which these recent amendments comply with the European Convention on Human Rights and the jurisprudence of the European Court of Human Rights and to identify human rights principles that need to be observed when implementing the amended provisions of the Law on Foreigners and International Protection. The article examines the amendments with regard to the following issues: detention of foreigners in transit zones (art. 7), alternatives to immigration detention (art 57/a), deportation appeals (art. 53) and interception of the detained migrants' electronic and communication devices (art 53).
\end{abstract}

* Dr. Öğr. Üyesi, Süleyman Demirel Üniversitesi Hukuk Fakültesi Milletlerarası Hukuk Anabilim Dal, E-Mail: meltemciger@sdu.edu.tr 
Keywords: Article 3 of the ECHR - Article 5 of the ECHR - Article 8 of the ECHR - Turkish Law on Foreigners and International Protection - Amendments of December 2019 - Alternatives to Immigration Detention - Deportation appeals

\section{GiRiş}

6 Aralık 2019 tarihinde 6458 Sayılı Yabancılar ve Uluslararası Koruma Kanunu’nun (YUKK) ${ }^{1}$ bazı maddelerinde değişiklik yapılmış ve kanuna ek maddeler getirilmiştir ${ }^{2}$. Kanundaki bu değişikliklerin bir kısmı Türkiye'deki göçmen³ ${ }^{3}$ uluslararası koruma başvurucusu ve uluslararası koruma statüsü sahibi birçok yabancının Avrupa İnsan Hakları Sözleşmesi (AİHS) tarafından da güvence altına alınan temel hak ve hürriyetlerine ilişkindir. Bu nedenle YUKK'da yapılan bu değişikliklerin insan haklarına uygunluğunun incelenmesi ve tartışılması büyük önem arz etmektedir. Literatürde Avrupa İnsan Hakları Sözleşmesi'ni ${ }^{4}$ ve sığınmacıların ve göçmenlerin AİHS kapsamındaki haklarını ${ }^{5}$ konu alan kapsamlı ve güncel çalışmalar mevcuttur. Bununla birlikte, makalenin yazım tarihinde, Yabancılar ve Uluslararası Koruma Kanunu'nda Aralık 2019'da yapılan değişiklikleri inceleyen akademik çalışma sayısı meslek örgütleri ve sivil toplum kuruluşları tarafından yayınlanan raporlar ${ }^{6}$ haricinde oldukça sınırlıdır ${ }^{7}$ Makalenin amacı anılan değişiklikleri AİHS ve ilgili Avrupa İnsan

16458 Sayılı Yabancılar ve Uluslararası Koruma Kanunu, R.G. Sayı: 28615, R.G. Tarih: 11/4/2013.

27196 sayılı Bazı Kanunlarda ve 375 Sayılı Kanun Hükmünde Kararnamede Değişiklik yapılmasına Dair Kanun, R.G. Sayı: 30988, R.G. Tarih: 24/12/2019.

3 Bu makaledeki göçmen terimi uluslararası hukuk esas alınarak, maddi ve sosyal koşullarını iyileştirmek ve kendileri ve ailelerine ilişkin beklentilerini geliştirmek amacıyla başka bir ülkeye veya bölgeye hareket eden kişileri kapsayacak şekilde kullanılmıştır. Bkz. IOM, Göç Terimleri Sözlüğ̈̈, 2. Baskı <https://publications.iom.int/system/files/pdf/iml31_ turkish_2ndedition.pdf> erişim tarihi: 10 Mayıs 2020.

4 David Harris, Michael O’Boyle, Ed Bates and Carla Buckley, Harris, O'Boyle \& Warbrick: Law of the European Convention on Human Rights, 3. Baskı, Oxford University Press, 2014; Alastair Mowbray, Cases, Materials, and Commentary on the European Convention on Human Rights, 3. Bask1, Oxford University Press, 2012; Şeref Gözübüyük, Feyyaz Gölcüklü, Abdurrahman Saygılı, Avrupa İnsan Hakları Sözleşmesi ve Uygulaması, 12. Bası, Turhan Kitapevi, 2019; Durmuş Tezcan, M. Ruhan Erdem, Oğuz Sancakdar, R. Murat Önok, Insan Hakları: El Kitabı, 8. Baskı, Seçkin Yayınevi, 2019; İlyas Doğan (Editör) Avrupa İnsan Hakları Sözleşmesi Hukuku, 1. Baskı, Astana Yayınlar1, 2019.

5 Cathryn Costello, The Human Rights of Migrants in European Law, 1 Baskı, Oxford University Press, 2015; İlke Göçmen, Avrupa İnsan Hakları Sözleşmesi Işı̆̆ında Avrupa Birliği ve Türkiye Göç Hukuku, 1. Baskı, Seçkin Yayınevi, 2015; Işıl Özkan, Göç ve Sı̆̆ınma Hukuku, 3. Baskı, Seçkin Yayınevi, 2018; Nuray Ekşi, Yabancılar ve Uluslararası Koruma Hukuku, 4. Baskı, Beta Yayınevi, İstanbul, 2017.

6 YUKK'da Aralık 2019'da yapılan değişikliklere dair baro ve sivil toplum kuruluşlarına ait rapor ve bildiriler için bkz. Antalya Barosu İnsan Hakları Merkezi, Dünya Evimiz Derneği, Uluslararası Dayanışma Derneği, Göç Araştırmaları Derneği (GAR), Göçmen Dayanışma Derneği, Hak İnisiyatifi Derneği, Halkların Dayanışma Köprüsü Derneği, İltica ve Göç Araştırmaları Derneği (İGAM), İnsan Hakları Derneği (İHD), İnsan Hakları Gündemi Derneği (İHGD), İzmir'de Suriyeli Mültecilerle Dayanışma Derneği, Kaos GL, Kırkayak Kültür, Medya ve Mülteci Hakları Derneği, Mültecilerle Dayanışma Derneği (Mülteci-der), Uluslararası Mülteci Hakları Derneği, Van Barosu, Yurttaşlık Derneği, Yuva Derneği, YUKK Değişiklikleri Hakkında Ortak Değerlendirme, 4 Aralık 2019 <https://www.gocarastirmalaridernegi.org/attachments/article/144/yukkdegisiklikleri-hakkinda-ortak-degerlendirme.pdf> erişim tarihi: 10 Mayıs 2020; Ankara Barosu Duyurusu, Yabancılar ve Uluslararası Koruma Kanunu'nda Yapılan Değişikliklerin Değerlendirilmesi, <http://ankarabarosu.org.tr/HaberDuyuru. aspx?DUYURU\&=4306> 10 Mayıs 2020; Uluslararası Mülteci Hakları Derneği, 6458 Sayılı Yabancılar ve Uluslararası Koruma Kanunu’nda Değişiklik Yapılmasına Dair Kanun Taslağı İncelemesi, Kasım 2019 < https://www.umhd.org.tr/wpcontent/uploads/2019/11/kanun-tasla\%C4\%9F\%C4\%B1-incelemesi.pdf> erişim tarihi: 10 Mayıs 2020.

7 Barış Teksoy, 'İdari Gözetim Altına Alınan Yabancıların Elektronik ve İletişim Cihazlarının İncelenmesine İlişkin 
Hakları Mahkemesi (AİHM) kararları ışı̆̆ında değerlendirmek ve söz konusu değişikliklerin uygulanması sırasında insan hakları bakımından dikkat edilmesi gereken hususları ortaya koymak suretiyle doktrine katkıda bulunmaktır ${ }^{8}$.

Makale altı kısımdan oluşmaktadır ve her kısımda önce ilgili kanun değişiklikleri ve AİHM içtihadı özetlenmiş daha sonra kanun değişiklikleri AİHS ve ilgili AİHM içtihadı sşığında değerlendirilmiştir. Birinci kısımda YUKK m. 53'de yapılan değişiklik ile sınır dışı kararlarına itiraz süresinin yedi güne indirilmesi hususu incelenmiştir. İkinci kısımda ise sınır dışı kararlarına yapılan itirazların tüm yabancılar için yürütmeyi durdurma etkisi doğuracağına dair YUKK m. 53’te yapılan değişiklik değerlendirilmiştir. Üçüncü kısımda YUKK m. 60/A ile yapılan gönüllü geri dönüşe ilişkin kanun değişikliği, dördüncü kısımda ise Türkiye’ye girişlerine izin verilmeyecek yabancıların sınır kapılarında bekletilmesine ilişkin YUKK m. 7'de yapılan değişiklik değerlendirilmiştir. Beşinci kısımda YUKK m. 57/A ile kanuna yeni getirilen idari gözetime alternatif yükümlülükler ve altıncı kısımda YUKK m. 57'de yapılan idari gözetim altına alınan yabancıların elektronik ve iletişim cihazlarının incelenebileceğine ilişkin kanun değişikliği AİHM içtihadı 1şı̆̆ında incelenmiştir.

\section{Sınır Dışı Kararına İtiraz Süresine İlişkin Değişikliğin Değerlendirilmesi}

\section{A. Kanun Değişikliği}

6/12/2019 tarihli ve 7196 sayılı Kanun'un 75. maddesiyle, YUKK m. 53(3)'de yer alan "on beş gün" ibaresi "yedi gün" şeklinde değiştirilmiştir. Bu değişiklik ile birlikte sınır dışı kararlarına itiraz süresi 15 günden yedi güne indirilmiştir.

\section{B. IIgili AiHM Kararları}

AİHM sınır dışı kararlarına itiraz süresini AİHS m. 3 ile bağlantılı olarak ve AİHS m. 13 ışı̆̆ında değerlendirmekte ve itiraz süresinin yabancıların etkili başvuru hakkını ihlal etmeyecek şekilde düzenlenmesi gerektiğine dikkat çekmektedir. ${ }^{9}$ AİHM I.M./Fransa kararında hem uluslararası koruma başvurusunda hem de sınır dışı kararına itiraz başvurusunda bulunma için öngörülen sürenin makul olmayan şekilde kısa olmaması gerektiğine vurgu yapmışıır ${ }^{10}$. Mahkeme sınır dışı kararına itiraz için tanınan sürenin makul olmayan derecede kısa olduğu durumlarda bunun AİHS m. 13’ü AİHS m. 3 ile bağlantılı olarak ihlal edeceğini belirtmiştir ${ }^{11}$.

Hükmün Değerlendirilmesi', Ankara Üniversitesi SBF Dergisi, 2020, 75.2: 517-556.

8 Makalede yer sınırlamalarından dolayı 7196 sayılı Kanun ile YUKK'da yapılan tüm değișiklikleri incelemek mümkün olmamış, sadece Avrupa İnsan Hakları Sözleşmesi ile ilgili görülen sayılı değişiklik incelenmiştir.

9 Marcelle Reneman, 'Speedy asylum procedures in the EU: Striking a fair balance between the need to process asylum cases efficiently and the asylum applicant's EU right to an effective remedy' International Journal of Refugee Law, 2013, 25.4:717-748, s. 732.

10 I.M./France App no 9152/09 (ECHR, 2 May 2012) para 127-160.

11 ibid, para 127-160. 
Makul olmayan derecede kısa sürenin ne olduğuna dair açık bir içtihat bulunmasa da AİHM, IM/ Fransa kararında sınır dışı kararına itirazda bulunma için verilen 48 saat sürenin etkili başvuru hakkını ihlal ettiğine karar vermiştir ${ }^{12}$. Mahkeme, ihlale karar verirken Sudan vatandaşı olan başvurucunun sınır dışı kararına itiraz süresinin kısalığından dolayı itiraz öncesinde avukatı ile detaylı olarak görüşememesini ve Sudan'da polis şiddetine maruz kalmasına dair kanıt sunacak yeterli zamanının olmamasını dikkate almıştır ${ }^{13}$. Görüldüğü üzere, AİHM I.M./ Fransa kararında AİHS m. 3’e ilişkin etkili başvuru yolunun var olup olmadığını tespit ederken sınır dışı kararına itiraz süresini, yabancının bu sürede itiraz başvurusu hazırlayabilme kabiliyetini ve avukata/ adli yardıma erişimini ve başvuruya ilişkin olarak kanıtlayıcı belge temin edebilme imkanını incelemiştir.

\section{Değerlendirme}

Sınır dışı kararının da idari bir karar olduğu ve 2577 sayılı İdari Yargılama Usulü Kanunu ${ }^{14}$ m. 7 uyarınca idari uyuşmazlıklarda dava açma süresinin yazılı bildirimin yapıldığı tarihten itibaren 30 gün olduğu dikkate alındığında sınır dışı kararına yapılacak itiraz süresinin yedi gün olarak belirlenmesi yabancılara özellikle idari gözetim altındaki kişilere itiraz başvurularını hazırlama, kanıtlayıcı belge tedarik etme ile avukata ve adli yardıma erişim için oldukça kısa bir süre tanınması anlamına gelmektedir. Özellikle idari gözetim altındaki yabancıların farklı dildeki resmî belgelerin içeriğini anlama, gözetim altında tutuldukları devletin yasal mevzuatı hakkında bilgi sahibi olma ve resmi makamlara başvuruda bulunma konusunda oldukça dezavantajlı bir pozisyonda bulundukları açıktır ${ }^{15}$. Geçmişte ülkemizde özellikle idari gözetim altındaki yabancıların avukata ve etkili başvuru hakkına erişimde yaşadığı zorluklar birçok AİHM kararına konu olmuştur ${ }^{16}$. Bu hususlar ışığında, özellikle idari gözetim altındaki birçok yabancının etkin başvuru hakkını kullanabilmeleri bakımından yedi günlük itiraz süresinin yeterli olmayacağ sonucu çıkmaktadır ${ }^{17}$. Yedi günlük itiraz süresinin birçok yabancının sınır dışı kararına etkin bir şekilde itiraz etme kabiliyetini kısıtladığı hususu ileride AİHM önüne gelecek davalarda da mahkemece dikkate alınacaktır.

12 ibid, para 160.

13 ibid, para 127-160.

142577 sayılı İdari Yargılama Usulü Kanunu, R.G. Sayı:17580, R.G. Tarih: 20/1/1982.

15 AYM, Yusuf Ahmed Abdelazım Elsayad (B. No: 2016/5604) 24/5/2018, para 65.

16 Abdolkhani and Karimnia v. Turkey App no 30471/08 (ECHR, 22 September 2009); AYM, Yusuf Ahmed Abdelazım Elsayad (B. No: 2016/5604) 24/5/2018.

17 Bu yönde ayrıca YUKK Değişiklikleri Hakkında Ortak Değerlendirme, 4 Aralık 2019 < https://www. gocarastirmalaridernegi.org/attachments/article/144/yukk-degisiklikleri-hakkinda-ortak-degerlendirme.pdf> erişim tarihi: 10 Mayıs 2020, s. 3; Uluslararası Mülteci Hakları Derneği, 6458 Sayılı Yabancılar ve Uluslararası Koruma Kanunu’nda Değişiklik Yapılmasına Dair Kanun Taslağı İncelemesi, Kasım $2019<$ https://www.umhd. org.tr/wp-content/uploads/2019/11/kanun-tasla\%C4\%9F\%C4\%B1-incelemesi.pdf> erişim tarihi: 10 Mayıs 2020, s. 6-8. 


\section{Sınır Dışı Kararına İtirazın Yürütmeyi Durdurmasına İliş̧kin Değişikliğin Değerlendirilmesi}

\section{A. Kanun Değişikliği}

6/12/2019 tarihli ve 7196 sayılı Kanun'un 75. maddesiyle, YUKK m. 53(3)'de yer alan “54'üncü maddenin birinci fikrasının (b), (d) ve (k) bentleri ile ikinci fikrası kapsamındakiler hariç”, ibaresi madde metninden çıkarılmıştır. Aralık 2019 değişikliği ile 3/10/2016 tarihli ve 676 sayılı KHK’nın ${ }^{18}$ 35 inci maddesiyle yapılan ve daha sonra kanunlaşan değişiklik geri alınmıştır. Maddenin son hali yabancının rızası saklı kalmak kaydıyla, dava açma süresi içinde veya yargı yoluna başvurulması hâlinde yargılama sonuçlanıncaya kadar yabancı sınır dışı edilmeyeceğini belirtmektedir.

\section{B. Ilgili AiHM Kararları}

Avrupa İnsan Hakları Sözleşmesi m.3 işkence yasağını "hiç kimse işkenceye, gayri insani yahut onur kırıcı ceza veya muameleye tabi tutulamaz" demek suretiyle düzenlemiştir. Mahkeme ilk defa 1989 tarihli Soering/ Birleşik Krallık kararında bir yabancının gönderileceği ülkede kötü muameleye maruz kalma riski olduğu hallerde gönderen devletin buna ilişkin bir sorumluluğu olduğuna hükmetmiştir. ${ }^{19}$ AİHM içtihatlarıyla zenginleşen insan hakları hukuku bir devletin yetki alanına giren kişilerin işkence, gayri insani yahut onur kırıcı ceza veya muamele riski olan bir ülkeye gönderilmesini yasaklamıştır. ${ }^{20}$

AİHM, Jabari/Türkiye ${ }^{21}$ kararında başvuruda AİHS m. 3’e ilişkin bir risk söz konusu ise yabancının AİHS m. 3’e ilişkin başvurusunun sınır dışı işlemini durdurma etkisine sahip olması gerektiğine karar vermiştir. Mahkeme M.A./ Kıbrıs kararında ${ }^{22}$ ise sınır dışı kararına itiraz başvuruşunun doğrudan (otomatik olarak) yürütmeyi durdurmamasının AİHS m. 3 ile ilişkili olarak AİHS m. 13’ü ihlal edeceğine karar vermiştir. Yine AİHM, Abdolkhani/Türkiye kararında Türkiye’de sınır dışı kararına karşı gidilebilecek hukuk yolunun etkili bir başvuru yolu olarak kabul edilemeyeceğini çünkü sınır dışı kararına karşı yapılan itirazların idare mahkemesinin verdiği yürütmeyi durdurma kararı olmadan sınır dışı kararının uygulanmasını durdurmadığı tespit etmiştir ${ }^{23}$. Mahkeme bugün başvurucunun sınır dışı edilmesi durumunda gönderileceği ülkede AİHS m. 2 (yaşam hakkı), AİHS m. 3 (işkence, insanlık dışı veya onur kırıcı muamele ve ceza) ve Ek Protokol No 4 m. 4’e (toplu sınır dışı yasağı) aykırı bir muamele göreceğine dair bir risk var ise, sınır dışı kararına itirazın otomatik olarak yürütmeyi durdurması gerektiğini kabul etmektedir ${ }^{24}$.

18 Olağanüstü Hal Kapsamında Bazı Düzenlemeler Yapılması Hakkında Kanun Hükmünde Kararname, Karar Sayısı: KHK/676, R.G. Sayı: 29872, R.G. Tarih: 29 Ekim 2016.

19 Soering v. UK App 14038/88 (ECHR, 7 July 1989); GÖZÜBÜYÜK, GÖLCÜKLÜ, SAYGILI, s. 204.

20 COSTELLO, s. 180-194.

21 Jabari v. Turkey App no 40035/98 (ECHR, 11 November 2000).

22 M.A.v. Cyprus App no 41872/10 (ECHR, 23 July 2013).

23 Abdolkhani and Karimnia v. Turkey App no 30471/08 (ECHR, 22 September 2009); J.R. and others v. Greece App no 22696/16 (ECHR, 25 January 2018) para 199.

24 De Souza Ribeiro v. France App no 22689/07 (ECHR, 13 December) para 82, 83. 


\section{Değerlendirme}

AİHM’nin yukarıda özetlenen kararlarına uygun olarak YUKK m. 53 sınır dışı kararına karşı idare mahkemesi önünde yapılacak itiraz sonuçlanana kadar yabancının sınır dışı edilmeyeceğini düzenlemekte idi. Söz konusu düzenleme 3/10/2016 tarihli ve 676 sayılı KHK’nın 35. maddesiyle değişikliğe uğratılmış, YUKK m. 54 (1) (b), (d) ve (k) bentleri kapsamındaki yabancıların sınır dışı edilmesi için yargılamanın sonuçlanmasının beklenmesine gerek olmadığı düzenlenmiş idi. Bu değişikliğin geri gönderme yasağını ihlal edebileceği ve AİHS m. 13 ve Anayasa m. 40’a aykırı sonuçlar doğurabileceği Anayasa Mahkemesi tarafından 30.05.2019 tarihinde verilen Y.T. Başvurusuna ilişkin kararda da teyit edilmiştir ${ }^{25}$. Söz konusu karar sonrasında 676 sayılı KHK’nın 35. maddesiyle yapılan değişikliğin geri alınması ve sınır dışı kararlarına itirazın doğrudan yürütmeyi durdurma etkisinin kanunda geri getirilmesi ile mevzuatımız AİHM içtihadına uygun hale gelmiştir ${ }^{26}$.

\section{Gönüllü Geri Dönüşe İlişkin Değişikliğin Değerlendirilmesi}

\section{A. IIgili Kanun Değişikliği}

6/12/2019 tarihli ve 7196 sayılı Kanun'un 75. maddesiyle, YUKK’a m. 60/A eklenmiştir. İlgili madde, hakkında sınır dışı etme kararı alınmış ve menşe ülkesine gönüllü olarak geri dönmek isteyen yabancılardan Göç İdaresi Genel Müdürlügü̉nün uygun gördügü kişilere ayni veya nakdi destek sağlanabileceğini ve düzensiz göçmenlerin gönüllü geri dönüşlerine ilişkin çalışmaların uluslararası kuruluşlar, kamu kurum ve kuruluşları ve sivil toplum kuruluşlarıyla iş birliği halinde yürütülebileceğini düzenlemektedir. Bu değişikliğin yanı sıra, YUKK m. 57/A ile geri dönüş danışmanlığı idari gözetime alternatif bir tedbir olarak hukukumuza getirilmiştir.

\section{B. IIgili AiHM Kararları}

Avrupa İnsan Hakları Mahkemesi gönüllü geri dönüş yardımı ve programlarını (assisted voluntary return) 2019 tarihli N.A./Finlandiya ${ }^{27}$ kararında ele almıştır. Irak vatandaşı Sünni mezhebine mensup bir Müslüman olan başvurucunun babasının Finlandiyada yaptı̆̆ı sığınma başvurusu ve başvuru sonucuna yaptığı itirazlar reddedilmiş ve kişi hakkında sınır dışı kararı verilmiştir ${ }^{28}$. Başvurucunun

25 Anayasa Mahkemesi bu kararda şu hususa dikkat çekmiştir: "Başvurucu; idare mahkemesinde görülecek davanın sonucunu bekleme imkânının bulunmadığını, davanın her aşamasında sııır dışı edilme olasıliğının söz konusu olduğunu dile getirmiştir. Başvurucunun idare mahkemesinde görülen davanın pratikte başarı şansı sunmadiğı için etkili bir başvuru yolu olmaktan çıktığı yönündeki iddiaları temelsiz değildir... Somut davada ortaya çıkan durum, idare mahkemesinin uygulamasından veya mevzuatı yanlış yorumlamasından değil 6458 sayıl Kanun'da yapılan değişiklikten kaynaklanmıştır. Bu değişikliğin Anayasa'da güvence altına alınan yaşam hakkı, kötü muamele yasağı, etkili başvuru hakkı ile Anayasa Mahkemesinin bu konudaki yerleşik içtihatlarıyla uyumlu olmadığı anlaşılmıştır.” AYM, Y.T. (B. No: 2016/22418) 30/5/2019 para 59, 60.

Ayrica bkz. Meltem Ineli-Ciger, Remedies Available against Asylum Decisions and Deportation Orders in Turkey: An Assessment in View of European Law and the European Convention on Human Rights' Nordic Journal of International Law, 2019, 88.2: 216-249, s. 243-248. 
babası bunun üzerine gönüllü geri dönüş yardımına başvurmuş, başvurusunun kabul edilmesi üzerine kendisine mali yardım yapılmış ve Irak’a dönmüştür ${ }^{29}$. Mali yardım karşılığında başvurucunun babası geri dönüşe gönüllü olarak rıza gösterdiğine ve bu yardımı yapan Birleşmiş Milletler Göç Örgütü (IOM) Finlandiya ofisinin ve Finlandiya devletinin Irak’a dönüşüyle ilgili olarak hiçbir şekilde sorumlu tutulamayacağına dair bir belge imzalamıştır ${ }^{30}$. Başvurucunun babası Irak’a dönüşünün ardından kimliği belirsiz kişilerce öldürülmüştür. Başvurucu, babasının Irak’a geri gönderilmesinin AİHS m. 2 ve m. 3 'ü ihlal ettiğinden bahisle Mahkeme’ye başvurmuştur ${ }^{31}$. Mahkeme başvurucunun iddialarını kabul ederek Finlandiyảnın başvurucunun babasının Irak’ta karışılabileceği riskleri yeterince incelemeyerek AİHS m. 2 ve m. 3 'ü ihlal ettiğine karar vermiştir ${ }^{32}$.

Dava sırasında Finlandiya hükümeti başvurucunun babasının kendi isteğiyle ve gönüllü geri dönüş yardımı alarak Irak’a döndügünü bu nedenle sınır dışı kararı ile kişinin Irak’ta öldürülmesi arasında nedensellik bağının bulunmadığını ve Irak’ta başvurucunun karşılaştığı AİHS m. 2 ve m. 3 ihlallerden dolayı Finlandiyảnın AİHS m. 1 uyarınca sorumlu tutulamayacağını öne sürmüştür ${ }^{33}$. Buna ilişkin olarak Mahkeme başvurucunun babası hakkında verilmiş bir sınır dışı kararı olduğunu, bu nedenle kişi gönüllü dönüş yardımı almamış olsa bile Irak̉a dönmesi gerekeceğini bu nedenle dönüşün gerçek anlamla gönüllü olarak kabul edilemeyeceğini belirterek Finlandiya hükümetinin AİHS m. l’e ilişkin argümanını reddetmiştir ${ }^{34}$.

Mahkeme başvurucunun babasının gönüllü dönüş yaptığına ve tüm sorumluluğun kendisinde olacağına dair imzaladığı belgenin geçerliliğine ilişkin olarak ise iki ihtimalin söz konusu olduğunu belirtmiştii ${ }^{35}$. Başvurucunun babası ya ikamet izni alarak yasal bir şekilde Finlandiya’da yaşama ihtimali olmaksızın geri dönüş amacıyla idari gözetim altında alınıp, Schengen bölgesine 2 yıl giriş yasağına tabi tutulup, Irak’a zorla geri gönderilecek ve Irak otoritelerinin dikkatini çekecek ya da Irak’a gönüllü olarak geri dönüp kötü muameleye maruz kalma riskini göze alacaktır ${ }^{36}$. Bu iki ihtimali göz önünde bulunduran Mahkeme başvurucunun babasının geri dönüşe ilişkin gerçek bir seçim şansı olmadığını bu nedenle imzaladığı belgenin herhangi bir geçerliliğinin olmadığına karar vermiş ve kişinin Irak’a geri dönüşünün Finlandiyảnın sorumluluğunda olduğunu tespit etmiştir ${ }^{37}$.

\section{Değerlendirme}

Geri dönüş danışmanlığı programları genellikle "geri dönüş öncesi yardım, transit geçiş desteği ve geri dönüş sonrası ulaşım ve uyum desteği sağlayan resmi ve gönüllü geri dönüş programları çevresinde

\footnotetext{
29 ibid, para 19, 20.

30 ibid, para 19, 20.

31 ibid, para 19, 20.

32 ibid, para 105.

33 ibid, para 47.

34 ibid, para 57.

35 ibid, para 60.

36 ibid, para 60.

37 ibid, para 60.
} 
gelişen tavsiye ve destek hizmetlerini kapsamaktadır" ${ }^{38}$. İnsan haklarına uygun etkin bir geri dönüş mekanizmasının unsurları: geri dönüşün tam anlamıyla gönüllü olması, geri dönüşün güvenli bir şekilde gerçekleşmesi ve geri dönüş mekanizmasının sürdürülebilir olması olarak belirlenebilir ${ }^{39}$. İlk bakışta idare tarafından verilmesi öngörülen gönüllü geri dönüş yardımlarının ve idari gözetime alternatif yükümlülük olarak geri dönüş danışmanlığının AİHS ihlallerine yol açması söz konusu değildir. Bununla birlikte, gönüllü geri dönüşte dikkat edilmesi gereken en önemli husus kişilerin dönüş kararını özgür iradesi ile ve bilinçli olarak vermesi, menşe ülkedeki durum ve buradaki riskler ile ilgili açık ve detaylı olarak bilgilendirilmesi ve hiçbir şekilde geri dönüşe zorlanmamasıdır ${ }^{40}$. AİHM N.A./Finlandiya kararında yabancının dönüş kararının gerçekten gönüllü olarak verip vermediğine ilişkin yaptığ 1 değerlendirmede somut olayda yabancının taraf devlette sahip olduğu imkanları ve geri dönüş dışında bir seçim şansının olup olmadığını değerlendirmiştir.

AİHM’nin N.A./Finlandiya kararından da anlaşılacağı üzere hakkında sınır dışı kararı bulunan bir yabancının ülkesine geri dönüşte gönüllü geri dönüş yardımından faydalanmasının veya dönüşün kendi sorumluluğunda olduğuna dair bir belge imzalamasının devletin AİHS m. 2 ve m. 3 kapsamındaki sorumlulukları bakımından bir etkisi bulunmamaktadır. ${ }^{41}$ Yabancının her ne isimli olursa olsun geri dönüşe zorlanması durumunda geri gönderildiği ülkede AİHS m. 2 ve m. 3’e aykırı bir muamele veya cezayla karşılaşması durumunda kişiyi geri gönderen devletin sorumluluğu söz konusu olacaktır.

\section{Türkiye'ye Girişlerine İzin Verilmeyecek Yabancıların Sınır Kapılarında Bekletilmesine İlişkin Değişikliğin Değerlendirilmesi}

\section{A. IIgili Kanun Değişikliği}

YUKK m. 6 (1) yabancıların Türkiye’ye girişlerinde seyahat belgelerini görevlilere göstermek zorunda olduğunu düzenlemektedir. YUKK m. 6 (4) ise Türkiye’ye giriş yapmak isteyen yabancının YUKK m. 7 uyarınca Türkiye’ye girişlerine izin verilmeyecek kişilerden olduğuna yönelik şüphe duyulması halinde, sorumlu kolluk birimi tarafından kapsamlı kontrol işlemi gerçekleştirilebileceğini düzenlemektedir. YUKK m. 6(5) kapsamlı belge kontrolüne tabi tutulması gerekli görülen yabancıların en fazla dört saat bekletilebileceğini, yabancının belge kontrolü sırasında her an

$38 \mathrm{CDDH}$, 'Analysis of the Legal and Practical Aspects of Effective Alternatives to Detention in the Context of Migration', CDDH(2017)R88add2, 2018, para 226.

39 Jeff Crisp, Kathy Long, 'Safe and Voluntary Refugee Repatriation: From Principle to Practice' Journal on Migration and Human Security, 2016, 4.3: 141-147; Ahmet İçduygu, Emre Ayaşlı, 'Geri Dönüş Siyaseti: Suriyeli Mültecilerin Dönüş Göçü İhtimali ve Gelecek Senaryoları’ MiReKoç Çalışma Notları, 2019, <https://mirekoc. ku.edu.tr/wp-content/uploads/2019/05/Mirekoc_Makale_GeriDonusSiyaseti.pdf> erişim tarihi: 10 Mayıs 2020, s.4.

40 James C. Hathaway, The Right of Refugees under International Law, Cambridge University Press, 2005 , s. 932.

41 Elina Nieminen, Elina Pekkarinen, 'N.A. v. Finland - On the quality of the national authorities' risk assessment and what the authorities should learn from the case' EJIL Talk!, 17 December $2019<$ https://www.ejiltalk.org/n-a-v-finland-onthe-quality-of-the-national-authorities-risk-assessment-and-what-the-authorities-should-learn-from-the-case/>erişim tarihi: 10 Mayıs 2020. 
ülkesine dönebileceğini veya dört saatlik süreyle sınırlı kalmaksızın ülkeye kabulle ilgili işlemlerin sonuçlanmasını da bekleyebileceğini belirtmektedir.

YUKK m. 7(1) uyarınca Türkiye'ye girişlerine izin verilmeyecek yabancıların kabul edilemeyen yolcu kapsamına alınması ve Türkiye’ye girişlerine izin verilmeyerek geri çevrilmesini düzenlemektedir. Türkiye’ye girişlerine izin verilmeyecek yabancılar YUKK m. 7’de şu şekilde sayılmıştır: pasaportu, pasaport yerine geçen belgesi, vizesi veya ikamet ya da çalışma izni olmayan yabancilar ile bu belgeleri veya izinleri hileli yollarla edindiği veya sahte olduğu anlaşılanlar; vize, vize muafiyeti veya ikamet izin süresinin bitiminden itibaren en az altmış gün süreli pasaport veya pasaport yerine geçen belgesi olmayanlar ve vize muafiyeti kapsamında olsalar dahi YUKK m. 15(1) uyarınca vize verilmeyecek yabancılar. YUKK m. 7(2), söz konusu maddeyle ilgili olarak yapılan işlemlerin geri çevrilen yabancılara tebliğ edilmesi gerektiğini ve tebligatta, yabancıların karara karşı itiraz haklarını etkin şekilde nasıl kullanabilecekleri ve bu süreçteki diğer yasal hak ve yükümlülüklerinin de yer alması gerektiğini düzenlemektedir. 6/12/2019 tarihli ve 7196 sayılı Kanun'un 70. maddesiyle YUKK m. 7’ye bir fikra eklenerek "Bu madde kapsamındaki yabancılar, işlemleri sonuçlanıncaya kadar sınır kapılarında kendileri için belirlenen alanlarda bekletilir” hükmü getirilmiştir. Bu değişiklik ile YUKK m. 7(1)'de kabul edilemeyen yolcu olarak nitelendirilen yabancıların havaalanlarındaki transit bölgeler de dahil olmak üzere sınır kapılarında kendileri için belirlenen alanlarda haklarındaki işlemler sonuçlanıncaya kadar tutulması öngörülmüştür.

\section{B. IIgili AiHM Kararları}

Avrupa İnsan Hakları Sözleşmesi m. 5 özgürlük ve güvenlik hakkını düzenlemektedir. ${ }^{42}$ AİHS m. 5 herkesin kişi özgürlüğü ve güvenliğine hakkı olduğunu ve bu özgürlüğün ancak AİHS m. 5(1)'de sayılan durumlarda kısıtlanabileceğini belirmektedir. ${ }^{43}$ Yabancıların sınır kapılarında bekletilmesine ilişkin bir davada AİHM öncelikle bu durumun kişinin özgürlüğünden mahrum bırakılmasını içerip içermediğini araştıracak, ancak söz konusu durumun AİHS m. 5 kapsamına girdiğini tespit ettikten sonra başvurucunun özgürlüğünden mahrum birakılmasının AİHS m. 5(1)'de yer alan istisnalardan biri kapsamına girip girmediğini değerlendirecektir. ${ }^{44}$ AİHS m. 5(1) (f) yabancıların usulüne aykırı surette ülke topraklarına girmekten alıkonması nedeniyle yasaya uygun olarak yakalanması veya tutulmasını özgürlük ve güvenlik hakkının meşru istisnalarından biri olarak saymaktadır. Ne var ki, kişinin yakalanması ve tutulması AİHS hükümlerine ve özellikle AİHS m. 3 ve m. 5'e uygun olmalı ve gözetim altında tutulan bireylere birtakım asgari güvenceler sağlanmalıdır ${ }^{45}$.

42 Göçmen ve sığınmacıların AİHS m. 5 kapsamındaki haklarını AİHM kararları ışı̆̆ında inceleyen çalışmalar için bkz. GÖÇMEN s. 348 - 389; ÖZKAN s.185-193; Nuray Ekşi, 6458 Sayll Yabancılar ve Uluslararast Koruma Kanunu’nda İdari Gözetim, 1.Baskı, Beta Yayınevi, 2014; TEZCAN, ERDEM, SANCAKTAR, ÖNOK, s. 261 vd.

43 GÖZÜBÜYÜK, GÖLCÜKLÜ, SAYGILI, s. 221.

44 GÖÇMEN, s. 353, 354.

45 Khlaifia and Others v. Italy [GC] App no 16483/12 (ECHR, 15 December 2016) para 163; M.S.S. v. Greece and Belgium [GC] App no 30696/09, (ECHR, 21 January 2011) para 216-218. 
Avrupa İnsan Hakları Mahkemesi'nin yabancıların havaalanlarındaki transit bölgeler de dahil olmak üzere sınır kapılarında bekletilmesine ilişkin birçok kararı mevcuttur. Amuur/Fransa ${ }^{46}$ davasında Somali vatandaşı başvurucular Paris’te bulunan havalimanının transit bölgesinde tutulmalarının AİHS m. 5’e aykırı olduğunu iddia etmiştir. AİHM, öncelikle başvurucuların Paris-Orly Havalimanı’nın transit bölgesinde tutulmalarının kişilerin özgürlüğünden mahrum bırakılması anlamına geldiğini, bu nedenle davada AİHS m. 5’in uygulanması gerektiğini tespit etmiştir. Mahkeme daha sonra Fransa'nın ülkeye giriş sonrasında iltica talebinde bulunan başvuruculara transit bölgede tutuldukları süre içerisinde adli yardıma erişim sağlamamasını ve Fransız kanunlarında başvurucuların transit bölgede tutulabilecekleri asgari bir sürenin bulunmamasını da dikkat alarak Fransa’nın AİHS m. 5(1) (f)'yi ihlal ettiğine karar vermiştir ${ }^{47}$.

AİHM Nolan ve K./Rusya kararında ise Rusya'ya giriş yasağı olan başvurucunun havalimanının transit bölgesinde küçük bir odada bir gece boyunca tutulmasını AİHS m. 5'e aykırı bulmuştur $^{48}$. Benzer şekilde, Mahkeme Riad ve Idiab/Belçika ${ }^{49}$ kararında, başvurucuların Brüksel Havalimanının transit bölgesinde 10 gün boyunca tutulmalarını AİHS m. 3 ve m. 5’e aykırı bulmuştur ${ }^{50}$. Mahkeme Belçika’nın AİHS m. 5’i ihlal ettiğine karar verirken şu hususları dikkate almıştır: Belçika’nın başvurucuların transit bölgede tutulmalarına dair geçerli bir gerekçe veya bir yasal dayanak gösterememesi; başvurucuların öngörülemez bir süre boyunca transit bölgede tutulmasının herhangi bir kanun hükmüne veya Mahkeme kararına dayanmaması; başvurucuların transit bölgede tutulurken hukuki danışmanlığa erişimde yaşadıkları zorluklar ve bu nedenle transit bölgede tutulmalarına karşı itiraz yoluna başvuru imkanlarının sınırlı olması ${ }^{51}$. Mahkeme, başvurucuların transit bölgede tutulma şartlarını AİHS m. 3 kapsamında da incelemiş ve başvurucuların transit bölgede temel ihtiyaçlarını karşılayamaması nedeniyle bu maddenin de ihlal edildiğine karar vermiştir ${ }^{52}$. AİHM bu kararda özellikle transit bölgelerin kişilerin uzun süre tutulması için uygun bir yer olmadığını, transit bölgede tutulan kişilerin açık havaya çıkma, fiziksel aktivite gerçekleştirme, dış dünyayla iletişim ve beslenme ihtiyacını karşılama imkanlarının bulunmadığını belirtmiştir ${ }^{53}$.

AİHM, 21 Kasım 2019 tarihli Z.A. ve Diğerleri/Rusya Kararında sığınma talebinde bulunan başvurucuların 5 ay ile 2 yıl arasında değişen sürelerde Sheremetyevo Havalimanının transit bölgesinde kalmak zorunda bırakılmalarının AİHS m. 3 ve 5’i ihlal ettiğine karar vermiştir ${ }^{54}$. Mahkeme, başvurucuların uzun zaman kalmaya elverişli olmayan kalabalık, 24 saat boyunca aydınlatılan transit bölgede banyo, mutfak, açı hava, sağlık hizmeti veya sosyal yardıma erişimleri olmadan uzun süre kalmak zorunda bırakılmalarını onur kırıcı muamele olarak değerlendirmiş ve Rusya’nın AİHS m.

\footnotetext{
46 Amuur v. France App no 19776/92 (ECHR, 25 June 1996); bkz ayrıca GÖÇMEN, s. 343, 344.

47 ibid, para 53, 54.

48 Nolan ve K. v. Russia App no 2512/04 (ECHR, 12 February 2009) para 97-100.

49 Riad ve Idiab v. Belgium App no 29787/03, 29810/03 (ECHR, 24 January 2008).

50 ibid, para 80; GÖÇMEN, s. 287, 288.

51 ibid, para 78.

52 ibid, para 106.

53 ibid, para 104.

54 Z.A. and others v. Russia App no 61411/15, 61420/15, 61427/15 ve 3028/16 (ECHR, 21 November 2019).
} 
3’ü ihlal ettiğine karar vermiştir ${ }^{55}$. AİHM ayrıca başvurucuların transit bölgede kalmaları ile ilgili herhangi bir idari kararın olmadığını ve transit bölgede tutulmalarının Rus hukukunda bir temelinin bulunmadığını da dikkate alarak AİHS m. 5(1)(f)'in de ihlal edildiğine karar vermiştir ${ }^{56}$. Mahkeme bu sonuca varırken Rus hukukunda transit bölgede yabancıların tutulmasına dair azami bir sürenin bulunmayışını ve başvurucuların tutuldukları süre boyunca transit bölgeden çıkmalarının imkânsız olduğunu dikkate almıştır. Bunların yanı sıra Mahkeme başvurucuların transit bölgede uzun süre tutulmalarını ve bunun idari gözetim amacıyla orantısız oluşunu ve başvurucuların uluslararası koruma başvurularının değerlendirilmesinde yaşanan gecikmeleri göz önünde bulundurmuştur ${ }^{57}$. Söz konusu kararlardan da anlaşılacağı üzere Mahkeme göçmenlerin havalimanlarının transit bölgelerinde uzun süre tutulmasını özgürlükten yoksunluk olarak kabul etmiş ve bu tür uygulamaların AİHS m. 5 kapsamında değerlendirilmesi gerektiğini ortaya koymuştur. ${ }^{58}$

Mahkemeye göre, devletler hassas durumdaki ve özel ihtiyaç sahibi yabancıların insan onuruna yakışır bir şekilde tutulmaları için gerekli tedbirleri almalı ve gözetim şartları bu kişilerin ihtiyaçlarını karşılayacak şekilde düzenlenmelidir ${ }^{59}$. Şu kişiler hassas durumdaki birey olarak nitelendirilebilir: refakatsiz çocuklar, aileleri ile seyahat eden çocuklar, hamile ve emziren kadınlar, beraberinde çocuğu olan yalnız anne ya da babalar, yaşlılar, işkence, kötü muamele, cinsel saldırı ya da diğer ciddi psikolojik, bedensel ya da cinsel şiddet mağdurları, insan ticareti mağdurları, cinsel yönelimi nedeniyle risk altındaki bireyler - LGBTİ (Lezbiyen, Gey, Biseksüel, Transgender ve İnterseks), zihinsel ya da fiziksel sağlık problemleri olan bireyler, intihara eğilimli kişiler, madde bağımlıları, mülteci, sığınmacı ve/veya vatansızlar ${ }^{60}$. Mahkemeye göre, hassas durumdaki bireyleri tespit etmek devletlerin sorumluluğundadır ${ }^{61}$. AİHM Salman/Türkiye kararında hassas durumdaki yabancıların gözetim altına alınmaları durumunda bazı özel koşulların sağlanması ve yabancıların gözetim altında tutuldukları yerde bazı ek hizmetlerin verilmesi gerektiğini belirtmiştir ${ }^{62}$. Bu kural sınır kapılarında bekletilen/tutulan yabancılar için de geçerlidir. Örneğin, sınır kapılarında bekletilmesi söz konusu olan kişi engelli bir birey ise bu kişilerin bekletildiği alanlarda engelli kişilerin ihtiyaçlarına uygun tuvalet ve banyo imkanları bulunmalı, temel ihtiyaçlarını diğer kişilere muhtaç kalmadan gidermeleri için gerekli tedbirler alınmalı ve gözetim altında tutuldukları yerlerde çeşitli alanların tekerlekli sandalye ile erişilebilir olması sağlanmalıdır ${ }^{63}$. Söz konusu ek hizmetler ve özel gözetim koşulları

55 ibid, para 187-194.

56 ibid, para 110.

57 ibid, para 157-171; TEZCAN, ERDEM, SANCAKTAR, ÖNOK, s. 261.

58 ECHR, Guide on the case-law of the European Convention on Human Rights Immigration, Updated on 30 April 2020, <https://www.echr.coe.int/Documents/Guide_Immigration_ENG.pdf?utm_source=flexmail\&utm_ medium=e-mail\&utm_campaign=nieuwsbriefvreemdelingenrechteninternationaalfamilierecht $2020 \mathrm{nr} 4 \& \mathrm{utm}_{-}$ content=guide+on+case+law++immigration + update+30+april+2020Z $>$ erişim tarihi: 10 Mayıs 2020, s.12.

59 Council of Europe Steering Committee for Human Rights (CDDH), 'Analysis of the Legal and Practical Aspects of Effective Alternatives to Detention in the Context of Migration', CDDH(2017)R88add2, 2018, para 52.

60 UNHCR-IDC, Vulnerability Screening Tool, 2016, <https://www.unhcr.org/protection/detention/57fe30b14/unhcr-idcvulnerability-screening-tool-identifying-addressing-vulnerability.html> erişim tarihi: 10 Mayıs 2020.

61 Thimothawes v. Belgium App no 39061/11 (ECHR, 4 April 2017).

62 Salman v Turkey [GC] App no 21986/93 (ECHR, 27 June 2000) para 99.

63 Asalya v. Turkey App no 43875 (ECHR, 14 April 2014); ÖZKAN, s. 192. 
diğer hassas durumdaki bireyler özellikle bebek ve çocuklu aileler, refakatsiz çocuklar, hamileler, emziren anneler gibi hassas durumdaki yabancılar için de sağlanmalıdır. Bunun aksi AİHS m. 3 ihlallerine neden olabilmektedir. AİHM, Mubilanzila Mayeka ve Kaniki Mitunga/Belçika ${ }^{64}$ kararında beş yaşındaki refakatsiz çocuğun transit bölgede 18 yaşından büyük bireyler için ayrılan alanda 2 ay boyunca tutulmasını AİHS m. 3 ihlali saymıştır. Bu kararlardan da anlaşılacağı üzere, Mahkeme göçmenlerin havalimanlarının transit bölgelerinde uzun süre tutulmasını idari gözetim ile eş değer tutmakta ve bu uygulamaları özellikle AİHS m. 3 ve m. 5 kapsamında incelemektedir.

Mahkeme yakın zamanlı kararlarında havalimanlarının transit bölgelerinde uzun süre tutulan göçmenlerin durumu ile devletlerin kara sınırlarında iltica başvurularının sonucunu bekleyen göçmenlerin durumu arasında bir ayrıma gitmiştir ${ }^{65}$. Ilias ve Ahmet/Macaristan ${ }^{66}$ kararında Bangladeş vatandaşı iki başvurucu Yunanistan, Makedonya ve Surbistan üzerinden Macaristan’a geçiş yaparken Röszke transit bölgesinde iltica başvurusunda bulunmuş, bu talepleri reddedilmiş, iltica kararına karşı yaptıkları itiraz başvurusu sonuçlanıncaya kadar transit bölgede 23 gün boyunca bekletilmişlerdir. Başvurucular transit bölgede kalışlarının AİHS m. 3 ve 5’i ihlal ettiğini iddia etmiştir. Mahkeme ise AİHS m. 5 'in başvurucuların transit bölgede tutulmalarına uygulanamayacağına karar vermiştir ${ }^{67}$. Mahkeme göçmenlerin kara sınırlarında tutulmasının AİHS m. 5 kapsamına girip girmediğine ilişkin yaptığı değerlendirmede başvurucunun kişisel durumunu ve başka bir ülkeye geri dönme seçeneği olup olmadığını; taraf devletin sınır kapılarında yabancılara uyguladığı hukuk rejimini ve söz konusu hukuk rejiminin güttüğü amacı; başvurucunun sınır kapılarında bekletilme süresi, bekletildiği süre zarfında yapılan işlemlerin amacı ve bu sürede başvurucunun sahip olduğu hakları ve başvurucunun tabi tutulduğu sinırlamaların türü ve derecesini incelemiştir. ${ }^{68}$ AİHM somut olayda AİHS m. 5'in uygulanmaması gerektiğine karar verirken başvurucuların Macaristan’a özgür iradeleri ile geldiklerini, transit bölgeden Mültecilerin Statüsüne Dair Sözleşme ve AİHS’ne taraf olan ve güvenli olarak kabul edilebilecek Sırbistan’a serbestçe geçebileceklerini, Macar otoritelerinin transit bölgede iltica başvurularını ivedilikle değerlendirdiğini, başvurucuların hassas durumdaki bireyler olmadığını ve transit bölgedeki şartların insani olduğunu göz önünde bulundurmuştur.

Yabancıların sınır kapılarında özellikle havalimanlarının transit bölgelerinde özgürlüklerinden mahrum bırakılmalarının AİHS m. 5’i ihlal etmemesi için gereken şartları sekiz başlıkta incelemek mümkündür69. Öncelikle sınır kapılarında ve transit bölgelerde tutulma gerekli, makul ve orantılı olmalı ve meşru bir amaca hizmet etmelidir ${ }^{70}$. AİHM, yabancıların gözetim altına alınmasının orantılı olup olmadığını değerlendirilirken yabancının özgürlüğünün mahrum bırakılması ile sonuçlanan

64 Mubilanzila Mayeka and Kaniki Mitunga v. Belgium App no 13178/03 (ECHR, 12 October 2006); ÖZKAN s.189.

65 Guide on the case-law of the European Convention on Human Rights, Immigration, s. 11.

66 Ilias and Ahmed v. Hungary App no 47287/15 (ECHR, 21 November 2019).

67 ibid, para 247.

68 ibid, para 217-218; Guide on the case-law of the European Convention on Human Rights, Immigration, s. 11.

69 Ayrıca bkz. International Commission of Jurists, European Council on Refugees and Exiles, Mültecilerle Dayanışma Derneği, Mülteci Hakları Merkezi, İdari Gözetim Altındaki Göçmen, Mülteci ve Sığınmacılar için Adalete Erişim Modül 2 (2019) <https://www.icj.org/wp-content/uploads/2019/02/MODULE2-Access-to-justice-for-migrants-refugees-andasylum-seekers-under-administrative-supervision-2019-TUR.pdf> erişim tarihi: 10 Mayıs 2020. 
tedbirin son çare olarak uygulanıp uygulanmadığını incelemektedir ${ }^{71}$. Orantılılık temel hak ve özgürlüklere yapılan sınırlama ile bu sınırlamanın sağladığı yarar ile hakkaniyete uygun bir dengenin bulunmasını gerektirmektedir ${ }^{72}$. Yabancının özgürlügünden yoksun bırakılmasının AİHS m. 5’e uygunluğu değerlendirilirken öncelikle şu üç soru cevaplanmalıdır: ulaşılmak istenilen amaç için özgürlükten yoksun bırakma tedbiri gerekli, elverişli ve orantılı mıdır; idari gözetim altında tutulmak istenilen kişinin özel ihtiyaç sahibi ve hassas durumdaki bir birey olup olmadığı değerlendirilmiş midir ve kişi hakkında tutulma tedbirleri yerine alternatif tedbirlere başvurulabilmesi mümkün müdür? ${ }^{73}$

İkinci olarak, sınır kapılarında ve transit bölgelerde tutulma kararı iç hukuk tarafından yetkilendirilmiş bir kişi veya kurum tarafından alınmalı ve gözetime ilişkin karar verme yetkisi iç hukukta açıkça düzenlenmiş olmalıdır ${ }^{74}$. Üçüncü olarak, sınır kapılarında ve transit bölgelerde tutulan kişilere gözetim altına alınmalarına dair nedenler en kısa sürede ve anladığı bir dilde aktarılmalıdır ${ }^{75}$. Dördüncü olarak, sınır kapılarında ve transit bölgelerde tutulma yabancının alıkonma amacına hizmet etmeye yetecek makul bir süre ile sınırlı olmalıdır, bunun aksi keyfi bir idari gözetim anlamına gelecek ve AİHS ihlallerine neden olacaktır ${ }^{76}$. AİHS m. 5(4)'e göre gözetim altında tutulan herkes, tutulma işleminin hukuka uygunluğu hakkında kısa bir süre içinde karar verilmesi ve eğer tutulma yasaya aykırı ise serbest bırakılması için bir mahkemeye başvurma hakkına sahiptir. Beşinci olarak, sınır kapılarında ve transit bölgelerde tutulma kararına karşı gidilebilecek bir hukuk yolu bulunmalıdır. Altıncı olarak, sınır kapılarında ve transit bölgelerde tutulan bir yabancının itiraz hakkını uygulamada da kullanabilmesi gerekmektedir ${ }^{77}$. Yedinci olarak, yabancıya avukata erişim ve mümkün ise adli yardım sağlanmalıdır ${ }^{78}$. Ayrıca AİHS m. 3 ve 13’ün bir gereği olarak sınır kapılarında ve transit bölgelerde tutulma süresince yabancı uluslararası koruma talebinde bulunabilmelidir ${ }^{79}$.

AİHS m. 5 ile ilgili güvencelerin yanı sıra, yabancıların sınır kapılarında tutulma şartları işkence, insani olmayan ve küçük düşürücü muamele ve ceza yasağına ve bu yasağı düzenleyen AİHS m. 3'e uygun olmalıdır. ${ }^{80}$ AİHM, M.S.S./Yunanistan ve Belçika kararında Afgan bir sı̆̆ınmacının Atina Havaalanının yakınında yer alan bir binada dar bir alanda 20 kişiyle birlikte tutulmasını özellikle açık

71 Tolga Şirin, Özgürlük ve Güvenlik Hakkı, Anayasa Mahkemesine Bireysel Başvuru Hakkı Serisi-1, MRK Baskı, 2018, s. 147.

72 Anayasa Mahkemesi, E. 2013/57, K. 2013/162, 26/12/2013; ŞİRİN, s. 148.

73 ŞİRIN s. 149; Ayrıca bu yönde bkz. Avrupa İşkencenin ve İnsanlık dışı veya Onur kırıcı Muamelenin veya Cezanın Önlenmesi Komitesi (CPT), 'Gözetim Altında Tutulan Yasa Dışı Göçmenler Bilgi Notu’ CPT/Inf(2017), 3 Mart 2019, $<$ https://rm.coe.int/1680727f8d> erişim tarihi: 10 Mayıs 2020.

74 Shamsa v. Poland App no 45355/99 and 45357/99 (ECHR, 27 November 2003).

75 AİHS m. 5(2).

76 Bkz. Saadi v. Italy [GC] App no 37201/06, (ECHR, 28 February 2008) para 74; Rustamov v. Russia App no 11209/103 (ECHR July 2012) para 150.

77 Z.N.S v. Turkey App no 21896/08 (ECHE, 19 January 2010) para 60.

78 Suso Musa v. Malta App no 42337/12 (ECHR, 23 June 2013) para 61; UNHCR, Guidelines on the Applicable Criteria and Standards relating to the Detention of Asylum-Seekers and Alternatives to Detention, $2012<$ https://www.refworld.org/ docid/503489533b8.html> erişim tarihi: 10 Mayıs 2020, para 47.

79 Guide on the case-law of the European Convention on Human Rights, Immigration, para 12.

80 İdari gözetim şartlarının AİHS’ne uygun olması için gerekenlere ilişkin olarak bkz. ÖZKAN, s.178-184; EKŞİ, s. 57-75. 
havaya çıkmasının yasak olması, tuvaletlere erişiminin resmi görevlilerin iznine bağlı olması, kirli yataklarda yatmak zorunda kalması ve yemek porsiyonlarının az olması nedeniyle küçük düşürücü muamele olarak kabul etmiş ve AİHS m. 3'e aykırı bulmuştur. ${ }^{81}$ Yabancıların gözetim şartlarının AİHS m. 3’e aykırı olmaması için Mahkeme asgari olarak aşağıdaki hususların gözetilmesi gerektiğini belirtmektedir. Öncelikle, yabancıların tutulduğu diğer yerlerde kişi başına düşen yaşam alanının üç metre kareden az olması, doğrudan AİHS m. 3 ihlali anlamına gelmektedir ${ }^{82}$. Eğer yabancıların tutulduğu diğer yerlerde kişi başına düşen yaşama alanının üç ile dört metre kare arasında veya dört metre kareden fazla olması durumunda AİHM idari gözetim yerlerinin diğer fiziki özelliklerini incelemektedir ${ }^{83}$. Mahkeme idari gözetim yerlerinin diğer fiziki özelliklerini incelerken gözetim altında tutulan yabancıların açı havaya, güneş ışığına erişimini; tutuldukları yerlerin yeterli havalandırmaya ve iklim özelliklerine göre yeterli 1sıtma ve soğutmaya sahip olup olmadığını ve temizlik durumunu incelemektedir ${ }^{84}$. Bunların yanı sıra, Mahkeme yabancinın temiz tuvalet, banyo gibi olanaklara erişimini ve bunları istediği zaman bireysel olarak kullanabilme imkanını ve yabancıya temiz yatak ve nevresim ile yeterli yemek ve su verilip verilmediğini incelemektedir ${ }^{85}$. AİHM söz konusu şartları sağlamayan bir yerde yabancıların tutulmasını insani olmayan muamele olarak nitelendirmektedir ${ }^{86}$.

\section{Değerlendirme}

AİHM yabancıların sınır kapılarında tutulmasına/bekletilmesine ilişkin olarak önüne gelen bir davada ilk olarak yabancının sinır kapısında tutulmasının/bekletilmesinin AİHS m. 5 uyarınca özgürlükten yoksun bırakılma olarak kabul edilip edilemeyeceğini değerlendirecektir. Mahkeme bu değerlendirmede şu ölçütleri dikkate alacaktır: başvurucunun kişisel durumu ve başka bir ülkeye dönme seçeneği olup olmadığı; devletin sınır kapılarında yabancılara uyguladığı hukuk rejimi ve söz konusu hukuk rejiminin güttüğü amaç; başvurucunun sınır kapılarında bekletilme süresi, bekletildiği süre zarfında yapılan işlemlerin amacı ve bu sürede başvurucunun sahip olduğu haklar ve başvurucunun tabi tutulduğu sınırlamaların cinsi ve derecesi. ${ }^{87}$ YUKK m. 7 'de sinırdan geri çevirmeye ilişkin olarak idari gözetimden bahsedilmese de ${ }^{88}$ YUKK m. 7 kapsamındaki yabancıların sınır kapılarında işlemleri sonuçlanıncaya kadar bekletilmesinin bazı durumlarda AİHS m. 5 kapsamında özgürlükten yoksun bırakılma olarak değerlendirilebileceği görüşündeyiz. Bunun

81 M.S.S. v. Yunanistan ve Belçika App no 30696/09 (ECHR, 21 January 2011) paras 232-234.

82 Mursic v. Croatia App no 7334/13 (ECHR, 20 October 2016) paras 103, 110.

83 Orchowski v. Poland App no 17885/04, (ECHR, 29 October 2009) para 122.

84 Mursic v. Croatia App no 7334/13 (ECHR, 20 October 2016) para 106: Khlaifia and Others v. Italy [GC] App no $16483 / 12$ (ECHR, 15 December 2016) para 198.

85 Mursic v. Croatia App no 7334/13 (ECHR, 20 October 2016) para 106: Khlaifia and Others v. Italy [GC] App no $16483 / 12$ (ECHR, 15 December 2016) para 198.

86 Dougoz v. Greece App no 40907/98 (ECHR, 6 March 2001).

87 Z.A. and others v. Russia App no 61411/15, 61420/15, 61427/15 ve 3028/16 (ECHR, 21 November 2019, para 138; Ilias and Ahmed v. Hungary App no 47287/15 (ECHR, 21 November 2019), para 217-218; Guide on the case-law of the European Convention on Human Rights, Immigration, s. 11, 12. 
nedeni kabul edilemez yolcu kapsamında sayılan yabancıların işlemleri sonuçlanıncaya kadar sınır kapılarında bekletilmesine ilişkin kanunda açık usuli ve hukuki güvencelerin yer almamasıdır.

Her ne kadar YUKK m. 6(5) kapsamlı belge kontrolüne tabi tutulan yabancıların transit bölgede en fazla dört saat bekletilebileceğini, yabancının belge kontrolü sırasında her an ülkesine dönebileceğini veya dört saatlik süreyle sınırlı kalmaksızın ülkeye kabulle ilgili işlemlerin sonuçlanmasını da bekleyebileceğini düzenlese de kanunda kabul edilemeyen yolcu kapsamında sayılan yabanciların sınır kapılarında bekletilmesine ilişkin azami bir süre belirlenmemiştir. ${ }^{89}$ Bunun yanı sıra, YUKK m. 7 kapsamındaki yabancıların sınır kapılarında fiili olarak tutulmalarına karşı gidilebilecekleri bir hukuk yolu da kanunda açıkça düzenlenmemiştir. Ayrıca YUKK m. 7 kapsamındaki yabancıların sınır kapılarında tutulduğu süre boyunca avukata erişimi büyük önem arz etse de uygulamada bazı avukatların sınır kapılarında tutulan müvekkillerine erişimde sorunlar yaşadığı belgelendirilmiştir ${ }^{90}$.

YUKK m. 7 uyarınca kabul edilmeyen yolcu kapsamındaki yabancıların sınır kapılarında işlemleri sonuçlanıncaya kadar bekletilmesinin/tutulmasının bazı durumlarda özgürlükten yoksun bırakılma olarak nitelendirilebileceği göz önünde bulundurularak YUKK uygulanmasının Sözleşmeyi ihlal etmemesi için şu hususlara mutlak olarak dikkat edilmesi gerektiği görüşündeyiz: öncelikle kabul edilmeyen yolcu kapsamındaki yabancının sınır kapılarında tutulmasına ilişkin olarak yabancının anlayabileceği bir dilde, gerekçeli bir karar alınmalı ve bu karar yabancıya tebliğ edilmelidir. İkinci olarak, yabancıların sınır kapılarında bekletilme/tutulmasına karşı gidilebilecek bir hukuk yolu bulunmalı ve yabancıya avukata erişim sağlanmalıdır. Üçüncü olarak, yabancılar sınır kapılarında uzun süre bekletilmemeli/tutulmamalıdır. Dördüncü olarak, sınır kapılarında bekletilen/tutulan yabancılar her aşamada uluslararası koruma talebinde bulunabilmelidir. Son olarak sınır kapılarında tutulma şartları AİHS m. 3’e uygun olmalı ve kişilere yukarıda belirtilen imkanlar ve hizmetler sağlanmalıdır. Eğer söz konusu yabancı hassas durumdaki bir birey ise bu durumda idare tarafından gerekli tedbirler alınmalıdır. Belirtilen hususların kanunda açıkça düzenlenmesi hukuki belirsizliği ortadan kaldıracak ve gelecekte uygulamada ortaya çıabilecek AİHS özellikle AİHS m. 3 ve m. 5 ihlallerinin önüne geçecek niteliktedir.

\section{4. İdari Gözetime Alternatif Yükümlülüklere İlişkin Değişikliğin Değerlendirilmesi}

\section{A. Ilgili Kanun Değișikliği}

6/12/2019 tarihli ve 7196 sayılı Kanun’un 77. ve 78. maddeleriyle YUKK m. 57’de yapılan değişiklik ve kanuna yeni getirilen m. 57/A ile hakkında sınır dışı etme kararı alınanlardan; kaçma ve kaybolma

89 Bu yönde ayrıca bkz. YUKK Değişiklikleri Hakkında Ortak Değerlendirme, 4 Aralık 2019 < https://www. gocarastirmalaridernegi.org/attachments/article/144/yukk-degisiklikleri-hakkinda-ortak-degerlendirme.pdf> erişim tarihi: 10 Mayıs 2020, s. 3; Uluslararası Mülteci Hakları Derneği, 6458 Sayılı Yabancılar ve Uluslararası Koruma Kanunu’nda Değişiklik Yapılmasına Dair Kanun Taslağı İncelemesi, Kasım 2019 < https://www.umhd.org.tr/wpcontent/uploads/2019/11/kanun-tasla\%C4\%9F\%C4\%B1-incelemesi.pdf> erişim tarihi: 10 Mayıs 2020, s. 2, 3.

90 Uluslararası Mülteci Hakları Derneği, 6458 Sayılı Yabancılar ve Uluslararası Koruma Kanunu’nda Değiş̧iklik Yapılmasına Dair Kanun Taslağı İncelemesi, Kasım 2019 <https://www.umhd.org.tr/wp-content/uploads/2019/11/ kanun-tasla\%C4\%9F\%C4\%B1-incelemesi.pdf> erişim tarihi: 10 Mayıs 2020, s. 3. 
riski bulunan, Türkiye'ye giriş veya çıkış kurallarını ihlal eden, sahte ya da asılsız belge kullanan, kabul edilebilir bir mazereti olmaksızın Türkiye'den çıkmaları için tanınan sürede çıkmayan, kamu düzeni, kamu güvenliği veya kamu sağllğı açısından tehdit oluşturan yabancılar veya bu kapsamda olup idari gözetimi sonlandırılan yabancılar hakkında idari gözetime alternatif yükümlülükler getirilebileceği düzenlenmiştir. ${ }^{91}$ YUKK m. 57(4) ayrıca idari gözetimin devamında zaruret görülmeyen yabancılara, 57/A maddesi uyarınca idari gözetime alternatif yükümlülükler getirileceğini belirtmektedir. YUKK m. 57/A ile Türk hukukuna belirli adreste ikamet etme, bildirimde bulunma, aile temelli geri dönüş, geri dönüş danışmanlığı, kamu yararına hizmetlerde gönüllülük esasıyla görev alma, teminat ve elektronik izleme olmak üzere yedi adet idari gözetime alternatif tedbir getirilmiştir. YUKK m. 57(2) fikrası kapsamında olup da idari gözetim altına alınmayan yabancılar hakkında bir veya birden fazla alternatif yükümlülüğe hükmedilmesi gerektiği ayrıca düzenlenmiştir.

YUKK m. 57/A(4) hakkında idari gözetime alternatif yükümlülüğe hükmedilen kişilere bu kararın gerekçeleri ile birlikte tebliğ edilmesini ve yabancının avukat tarafından temsil edilmediği durumlarda ise yabancının kendisine veya yasal temsilcisine kararın sonucu, itiraz usulleri ve süreleri hakkında bilgilendirilme yapılması düzenlenmiştir. YUKK m. 57/A(5)'de ise elektronik izleme yükümlülüğüne ilişkin olarak öngörülen itiraz merci sulh ceza hâkimi olarak belirlenmiştir. YUKK m. 57/A(5)'de ayrıca itiraz başvurusunun yabancının tabi tutulduğu idari yükümlülüğü durdurmayacağı ve sulh ceza hâkiminin incelemeyi beş gün içinde sonuçlandırması düzenlenmiştir. İlgili maddeye göre sulh ceza hâkiminin kararı kesindir ve bir üst mahkemeye itiraz mümkün değildir. YUKK m. 57/A(7)'de ise, yabancıya teminat yükümlülügü getirilmesi ve yabancının teminat süresi içerisinde mücbir sebepler ve mahkeme sürecinin sona ermemesi halleri saklı kalmak kaydıyla Türkiyeden çıkmaması durumunda teminatın Hazineye irat olarak kaydedileceği düzenlenmiştir.

\section{B. IIgili AiHM Kararları}

Avrupa İnsan Hakları Mahkemesi idari gözetim tedbirinin gerekli, makul ve orantılı olması gerektiğini belirtmektedir ${ }^{92}$. Mahkeme bir idari gözetim tedbirinin gerekli ve orantılı olup olmadığını değerlendirilirken idari gözetimin son çare olarak uygulanıp uygulanmadığını incelemektedir ${ }^{93}$. Bir diğer deyişle idari gözetimin gerekli ve orantılı olduğunu doğrulamak için Mahkeme başvurucu hakkında idari gözetim yerine uygulanabilecek daha az kısıtlayıcı bir tedbir olup olmadığını değerlendirmektedir ${ }^{94}$.

AİHM özellikle çocuklar ve çocuklu aileler gibi hassas durumdaki yabancılar hakkında idari gözetim kararı verilmeden önce alternatif tedbirlerin değerlendirilmesinin zorunlu olduğuna dair birçok

91 Bu kısımda incelenen idari gözetime alternatif tedbirlerin daha kapsamlı şekilde değerlendirildiği bir çalş̧ma için bkz. Meltem İneli Ciğer, 'Uluslararası Hukuk ve Karşılaştırmalı Hukukta İdari Gözetime Alternatif Tedbirler' Milletlerarası Hukuk ve Milletlerarası Özel Hukuk Bülteni, 2020, 40.2, s. 809 - 839.

92 A.B. and Others v France App no 11593/12 (ECHR, 12 July 2016).

93 ŞİíN, s. 147.

94 Alice Bloomfield, 'Alternatives to Detention at a Crossroads: Humanisation or Criminalisation?' Refugee Survey Quarterly, 2016, 5.1:29-46, s. 36. 
karar vermiştir ${ }^{95}$. Örneğin, AİHM Popov/Fransa kararında idari gözetim altına alınan çocuklu bir ailenin idari gözetimine ilişkin olarak, idari gözetimin meşru bir amaca hizmet etmesi gerektiğine dikkat çekerek söz konusu davada çocuklu ailenin idari gözetiminin son çare olup olmadığının değerlendirilmemesini ve idari gözetime alternatif tedbirlerin araştırılmamasını AİHS m. 5(1)'e aykırı bulmuştur $^{96}$. AİHM G.B. ve diğerleri/Türkiye kararında ise bir anne ve üç çocuğunun 2014 yllında Kumkapı Geri Gönderme Merkezi ve Gaziantep Geri Gönderme Merkezinde tutulması ile ilgili olarak AİHM m. 3, m. 5 ve m. 13'ün ihlal edildiğine karar vermiştir ${ }^{97}$. Söz konusu kararda Mahkeme uluslararası hukukta sadece çocuklar hakkında değil aynı zamanda onların aileleri hakkında da idari gözetim kararı verilmeyip idari gözetim alternatiflerine hükmedilmesi yönünde bir eğilim olduğunu ve çocuğun yüksek menfaati için idari mercilerin imkanlar dahilinde idari gözetim yerine alternatif tedbirlere hükmetmesi gerektiğini belirtmiştir ${ }^{98}$.

AİHM sadece çocuk ve çocuklu ailelerin değil hasta bireylerin idari gözetimine ilişkin yapılacak değerlendirmede de idari gözetime alternatif tedbirlerin dikkate alınmasını öngörmektedir. Örneğin, Mahkeme YohEkale Mwanje/Belçika kararında HIV pozitif olan Kamerun vatandaşı başvurucunun sınır dışı öncesi yedi hafta boyunca idari gözetim altında tutulmasını özellikle idari gözetim boyunca sağlık durumunun kötüleşmesi ve idari gözetim yerine geçici ikamet izni gibi alternatiflerin gözden geçirilmemesi nedeniyle AİHS m. 5’i ihlal ettiğini belirtmiştir ${ }^{99}$. AİHM içtihadına göre çocuklar ve çocuklu aileler ve ciddi hastalığı olan bireyler gibi hassas durumdaki kişilerin ve özel ihtiyaç sahiplerinin idari gözetimi son çare olmalıdır. Söz konusu kişilerin idari gözetimi ile ilgili olarak idari gözetim kararı alınmadan önce ve bu karar gözden geçirilirken ilk olarak idari gözetime alternatif tedbirler değerlendirilmeli ancak bu tedbirlerin uygulanması mümkün değil veya söz konusu tedbirler yeterli değil ise idari gözetime karar verilmelidir.

İdari gözetime alternatif tedbirlere atıf yapılan diğer AİHM kararları da öngörülebilir ve makul bir sürede sınır dışı edilme ihtimali olmayan kişilerin idari gözetimine ilişkin olanlardır. AİHM Louled Massoud/Malta kararında deniz yoluyla ülkeden kaçmanın kişinin hayatını tehlikeye atmadan mümkün olmadığı ve hava yolu ile ülkeden ayrılmanın sıkı kontrollere bağlı olduğu Malta gibi bir adada Cezayir vatandaşı olan başvurucunun yakın bir tarihte sınır dışı edilme ihtimalinin bulunmamasına rağmen idari mercilerin, idari gözetime alternatif hiçbir tedbiri uygulamayarak kişiyi 18 ay ve dokuz gün süre ile idari gözetim altında tutmasını keyfi tutulma sayıp söz konusu idari gözetimin AİHS m. 5(1) ve m. 5(4)'ü ihlal ettiğine karar vermiştir ${ }^{100}$. AİHM, S.Z./Yunanistan kararında ise pasaportundan Suriye vatandaşı olduğu açık olan başvurucunun, Suriye'deki iç savaş nedeniyle 2013 yılında sınır dışı edilmesinin mümkün olmadığı hususu ve kişi hakkında hükmedilebilecek idari gözetime alternatif tedbirler göz önünde bulundurulmadan idari gözetim

95 Popov v. France App no 39472/07 and 39474/07 (ECHR, 19 January 2012) para 119, 141; A.B. and Others v France App no 11593/12 (ECHR, 12 July 2016) para 120,123,124.

96 Popov v. France App no 39472/07 and 39474/07 (ECHR, 19 January 2012); GÖÇMEN, s. 367.

97 G.B. and others v. Turkey App no 4633/15 (ECHR,17 October 2019).

98 ibid, para 168.

99 YohEkale Mwanje v. Belgium App no 10486/10 (ECHR, 20 December 2011) para 124.

100 Louled Massoud v. Malta App no 24340/38 (ECHR, 27 October 2010). 
altında tutulmasını AİHS m. 5(1)(f) ve m. 5(4)'e aykırı bulmuştur ${ }^{101}$. Benzer şekilde, Mahkeme S.K./Rusya kararında 2015 yılında Rusya'da hakkında sınır dışı kararı verilen idari gözetim altındaki Suriye vatandaşı başvurucunun idari gözetimine ilişkin olarak AİHS m. 5'in ihlal edildiğine karar vermiştir ${ }^{102}$. İhlal nedeni Rus mercilerinin başvurucunun Suriye’ye sınır dışı edilmesinin Şubat ve Mart 2015'de kötüleşen iç savaş nedeniyle mümkün olmadığı hususunun ve idari gözetime alternatif tedbirlerin göz önünde bulundurmayarak idari gözetim kararını gözden geçirmemiş olmasıdır ${ }^{103}$.

Yukarıda incelenen AİHM kararlarından anlaşılacağı üzere çocuklar, çocuklu aileler, hasta kişiler gibi hassas durumdaki bireyler ve öngörülebilir ve makul bir süre içerisinde sınır dışı edilmesi mümkün olmayan yabancılar hakkında idari gözetime değil imkanlar dahilinde idari gözetime alternatif tedbirlere hükmedilmelidir. Mahkeme söz konusu idari gözetime alternatif tedbirlerin ne olduğunu açık olarak belirtmese de, çeşitli devletler tarafından uygulanan idari gözetime alternatif tedbirler arasında bildirim yükümlülükleri, seyahat dokümanına el konulması şartıyla salıverilme, devlet tarafından belirlenen yerlerde, açık ve yarı açı merkezlerde veya geri dönüş evlerinde kalma zorunluluğu, ikamet sınırlamaları, vaka yönetimi, geri dönüş danışmanlığı, teminat, garantör/ destekçi gösterme ve elektronik kelepçe, ses ve uydu teknolojileri ile izleme yer almaktadır ${ }^{104}$. AİHM şu ana kadar göç bağlamında uygulanan idari gözetime alternatif bir yükümlülüğün insan haklarına ve özellikle AİHS’ne uygunluğuna dair somut bir karar vermemiştir. Buna rağmen, idari gözetim gibi birçok idari gözetime alternatif tedbir de kişi özgürlüğü ve güvenliği hakkı başta olmak üzere gibi bazı temel insan haklarına kısıtlama getirebilmektedir. Bu nedenle idari gözetim gibi idari gözetime alternatif tedbirler de AİHS’ne uygun olmalı ve birtakım asgari insan hakları güvencelerini gözetmelidir ${ }^{105}$.

\section{Değerlendirme}

İdari gözetime alternatif yükümlülükler ile ilgili YUKK değişikliklerinin AİHM kararları 1şığında değerlendirilmesine ilişkin olarak öncelikle şunu belirtmek gerekir ki; idari gözetime alternatif yükümlülüklerin temel insan haklarına ne ölçüde kısıtlama getirdiği o yükümlülüğün kim hakkında verildiği ve hangi şartlar altında uygulandığı ile ilgili bir meseledir. Bununla birlikte genel olarak idari gözetime alternatif tedbirlerin idari gözetime göre daha insani olduğu, temel hak ve özgürlüklere daha az kısitlama ve kamu maliyesine daha az yük getirdiği kabul edilmektedir ${ }^{106}$.

101 S.Z. v. Greece App no 66702/13 (ECHR, 21 June 2018) paras 57-60, 73.

102 S.K. v. Russia App no 52722/15 (ECHR, 14 February 2017).

103 ibid, para 115-117.

104 Council of Europe Steering Committee for Human Rights (CDDH), 'Analysis of the Legal and Practical Aspects of Effective Alternatives to Detention in the Context of Migration, CDDH(2017)R88add2, 2018, para 100-114.

105 Khlaifia and Others v. Italy [GC] App no 16483/12 (ECHR, 15 December 2016) para 163; UNHCR-OHCHR, Global Roundtable on Alternatives to Detention of Asylum-seekers, Refugees, Migrants and Stateless Persons, Summary Conclusions, Geneva, 2011 <https://www.ohchr.org/Documents/Issues/Migration/Events/SummaryConclusions.pdf> erişim tarihi: 10 Mayıs 2020, para 18.

106 International Detention Coalition (IDC), There are Alternatives: A handbook for preventing unnecessary immigration detention (revised edition 2015), <https://idcoalition.org/wp-content/uploads/2015/10/There-Are-Alternatives-2015. pdf> erişim tarihi: 10 Mayıs 2020, s. 3. 
Bildirim yükümlülügü ve belirli adreste ikamet etme yükümlülükleri, bu tedbirlerin keyfi bir şekilde uygulanmaması şartıyla insan haklarına ciddi bir müdahale getirmemektedir. Daha önce belirtildiği üzere, geri dönüş danışmanlığında esas olan geri gönderme yasağının gözetilmesi, kişilerin dönüş kararını özgür iradesi ve bilinçli olarak vermesi, menşe ülkedeki durum ve buradaki riskler ile ilgili açı ve detaylı olarak bilgilendirilmesi ve hiçbir şekilde geri dönüşe zorlanmamasıdır. Aile temelli geri dönüş tedbirinde ise yabancının garantörlüğünü üstelenen aile ve akrabalara ilişkin yükümlülük ve sorumluluklar insan haklarına uygun olarak mevzuatta açıkça düzenlenmelidir. Bununla birlikte, insan haklarına kısıtlama getirebilecek ve AİHS ile uygunluğu problem teşkil edebilecek kanuna getirilen üç alternatif yükümlülüğün teminat, kamu yararına hizmetlerde gönüllülük esasıyla görev alma ve elektronik kelepçe kullanılması yoluyla elektronik izleme olduğu görüşündeyiz.

AİHM bugüne kadar kamu yararına hizmetlerde gönüllülük esasıyla görev alma gibi bir idari gözetime alternatif tedbirin AİHS’ne uygunluğuna dair bir karar vermiş değildir ${ }^{107}$. AİHS m. 4 kölelik ve zorla çalıştırma yasağını düzenlemektedir. AİHS m. 4(2) "Hiç kimse zorla çalıştrılamaz ve zorunlu çalışmaya tabi tutulamaz" hükmünü içermektedir. Mahkeme zorla çalıştırma kavramını Uluslararası Çalışma Örgütü’nün 29 sayılı Sözleşmesi ışı̆̆ında yorumlamış ve zorla çalıştırmanın "bir kişiden herhangi bir ceza tehdidiyle yapması istenen ve kişinin gönüllü olarak yapmadığı tüm iş veya hizmetleri" kapsadığını kabul etmiştir ${ }^{108}$. AİHS m. 4 (3)'de "Aşağıdaki haller, bu madde anlamında "zorla çalıştırma ya da zorunlu çalş̧ma" sayılmaz: ...(c) Bu Sözleşmènin 5. maddesinde [özgürlük ve güvenlik hakkı] öngörülen koşullara uygun olarak tutulu bulunan bir kimseden, tutulu bulunduğu sırada veya şartlı tahliyeden yararlandığı süre içinde olağan olarak yapması istenilen bir iş" ibaresi yer almaktadır. İdari gözetime alternatif bir tedbir olarak kamu yararına hizmetlerde gönüllü çalışmanın AİHS m. 4'e uygunluğu incelenirken söz konusu çalışmanın hakkında idari gözetime alternatif tedbire hükmedilen yabancı için 'olağan' olarak kabul edilip edilemeyeceğini değerlendirilecektir ${ }^{109}$.

YUKK m. 57/A ile hukukumuza idari gözetime alternatif bir tedbir olarak getirilen kamu yararına hizmetlerde gönüllülük esasıyla görev alma tedbirine ilişkin olarak detaylı düzenleme kanunda yapılmamıştır. Özellikle hakkında bu tedbire hükmedilen yabancıların tam olarak hangi iş kollarında, hangi süre ve sıklıkla çalıştırılabileceği açıkça kanunda düzenlenmiş değildir. Her ne kadar söz konusu tedbirin gönüllülük esasına dayanacağı kanunda düzenlenmişse de kamu yararına hizmetlerde gönüllülük esasıyla görev alma tedbirinin özellikle belirtilen hususların mevzuatta açık ve detaylı şekilde AİHS m. 4 gözetilerek düzenlenmesi gerektiği görüşündeyiz.

Finansal teminat, göç bağlamında nispeten daha az kullanılan bir idari gözetim alternatifidir. Bunun nedeni de çoğunlukla hakkında sınır dışı etme kararı alınan yabancının finansal teminat gösterecek

107 AİHM'in mahkumların tutuklu bulundukları süre içerisinde yaptıkları işlerin AİHS m. 4'e uygunluğuna dair verdiği kararlar için bkz. ECHR, Guide on Article 4 of the European Convention on Human Rights

Prohibition of slavery and forced labour, Updated on 31 December 2019, < https://www.echr.coe.int/Documents/ Guide_Art_4_ENG.pdf> erişim tarihi: 10 Mayıs 2020.

108 Van der Mussele v. Belgium App no 8919/80 (ECHR, 23 November 1983) para 32; Ali Bal, 'Kölelik, Zorla Çalıştırma ve Benzer Uygulamalara İlişkin Yasağın Uluslararası Hukuk ve AİHM İçtihatları Çerçevesinde Gelişimi' Yıldırım Beyazıt Hukuk Dergisi, 2019, 2: 55-112, s. 84.

109 Hangi işlerin olağan olduğuna dair değerlendirmede Mahkeme ulusal hukuk kurallarını dikkate almaktadır. Bkz. Stummer v. Austria App no 37452/02 (ECHR, 7 July 2011) para 128. 
yeterli maddi gücünün olmamasıdır ${ }^{110}$. AİHM bugüne kadar idari gözetime alternatif bir tedbir olarak teminatın AİHS’ne uygunluğuna dair herhangi bir karar vermemiştir. Bununla birlikte, teminatın AİHS m. 6 ile güvence altına alınan adil yargılanma hakkı kapsamında incelendiği bir davada Mahkeme teminatın meşru bir amaca hizmet etmesi ve orantılı olması gerektiğini ifade etmiş̧iir ${ }^{111}$. Makul olarak belirlenmeyen bir teminat bedelinin ${ }^{112}$ kişinin idari gözetime ilişkin yükümlülüklerine uymaması ve hazineye irat edilmesi durumunda AİHS Ek Protokol m. $1^{113}$ ile güvence altına alınan mülkiyet hakkına kısıtlama getirebileceği görüşündeyiz. Bu nedenle teminat bedeline ilişkin yapılacak yasal düzenlemede ve bu tedbire ilişkin uygulamada yabancıların mülkiyet hakkı ve teminatın orantılı olarak belirlenmesi gereği de dikkate alınmalıdır ${ }^{114}$.

Son olarak elektronik kelepçenin AİHS’ne uygunluğunu değerlendirmek yerinde olacaktır. Elektronik kelepçe hukukumuza yeni getirilen idari gözetime alternatif yükümlülükler arasinda temel insan haklarına özellikle kişi özgürlügü ve güvenliği hakkı, hareket özgürlüğü ve özel hayat ve aile hayatına saygı gösterilmesi haklarına en ciddi ve ağır müdahaleyi içeren tedbir olarak kabul edilebilirr ${ }^{115}$. Elektronik kelepçe kullanımının insan haysiyeti üzerinde olumsuz bir etki yarattı̆̆ 1 birçok rapor tarafından belirtilmiştir ${ }^{116}$. Söz konusu raporlarda elektronik kelepçelerin kişilerde strese neden olduğu ve kişileri sosyal tecrit altında hissettirdiği de ayrıca gözlemlenmiştir ${ }^{117}$. Bunun yanı sıra, elektronik kelepçe takılan yabancının anne veya baba olması durumunda, bundan çocukların

110 European Union Agency for Fundamental Rights (FRA), Alternatives to detention for asylum seekers and people in return procedures, $2015<$ https://fra.europa.eu/en/publication/2015/alternatives-detention-asylum-seekers-and-people-returnprocedures $>$, s. 2 .

111 Tolstoy Miloslavsky v. UK App no 18139/91, 13 July 1995; Işıl Özkan, 'Adil Yargılanma Hakkının Uluslararası Özel Hukuka Etkisi, Dokuz Eylül Hukuk Fakültesi Dergisi, Prof. Dr. Șeref Ertaşa Armağan, 2017, 19:1767-1834, s. 1778.

112 Teminat bedelinin kanunda makul olarak belirlenmesi gereğine ilişkin olarak ayrıca bkz. CDDH, 'Analysis of the Legal and Practical Aspects of Effective Alternatives to Detention in the Context of Migration', CDDH(2017)R88add2, 2018, para 228.

113 AİHS Ek Protokol m. 1 mülkiyet hakkını şu şekilde güvenceye altına almıştır: "Her gerçek ve tüzel kişinin mal ve mülk dokunulmazlı̆ııa saygı gösterilmesini isteme hakkı vardır. Bir kimse, ancak kamu yararı sebebiyle ve yasada öngörülen koşullara ve uluslararası hukukun genel ilkelerine uygun olarak mal ve mülkünden yoksun bırakılabilir. Yukarıdaki hükümler, devletlerin, mülkiyetin kamu yararına uygun olarak kullanılmasını düzenlemek veya vergilerin ya da başka katkıların veya para cezalarının ödenmesini sağlamak için gerekli gördükleri yasaları uygulama konusunda sahip oldukları hakka halel getirmez."

$114 \mathrm{Bu}$ düzenlemede Anayasa m. 35 de dikkate alınmalıdır. Anayasa m. 35 mülkiyet hakkını şu șekilde güvenceye altına almıștır: "Herkes, mülkiyet ve miras haklarına sahiptir. Bu haklar, ancak kamu yararı amacıyla, kanunla sinırlanabilir. Mülkiyet hakkının kullamilması toplum yararına aykırı olamaz."

115 UNHCR-OHCHR, Global Roundtable on Alternatives to Detention of Asylum-seekers, Refugees, Migrants and Stateless Persons, Summary Conclusions, Geneva, $2011<\mathrm{https} / /$ www.ohchr.org/Documents/Issues/Migration/Events/ SummaryConclusions.pdf $>$ erişim tarihi: 10 Mayıs 2020, para 21.

116 ibid, para 21; Alternatives to Immigration and Asylum Detention in the EU Time for Implementation, Philippe De Bruycker, Alice Bloomfield, Evangelia (Lilian) Tsourdi Joanna Pétin (Eds.) (2015) < https://odysseus-network.eu/wpcontent/uploads/2015/02/FINAL-REPORT-Alternatives-to-detention-in-the-EU.pdf> erişim tarihi: 10 Mayıs 2020, s.103; Jesuit Refugee Service, From Deprivation to Liberty: Alternatives to detention in Belgium, Germany and the United Kingdom, December 2011, available at: https://www.refworld.org/docid/4f0c10a72.html [accessed 13 May 2020].

117 BLOOMFIELD s. 40, 41; Alternatives to Immigration and Asylum Detention in the EU Time for Implementation, Philippe De Bruycker, Alice Bloomfield, Evangelia (Lilian) Tsourdi Joanna Pétin (Eds.) (2015) < https://odysseusnetwork.eu/wp-content/uploads/2015/02/FINAL-REPORT-Alternatives-to-detention-in-the-EU.pdf >erişim tarihi: 10 Mayıs 2020, s.103. 
da olumsuz etkilendiği belgelenmiştir ${ }^{118}$. Özellikle herhangi bir suçtan hüküm giymemiş göçmen ve sığınmacılar hakkında bu idari tedbire hükmedilmesi, bu kişilerin hükümlü gibi muamele görmesine neden olabilmektedir ${ }^{119}$.

AİHM bugüne kadar elektronik kelepçenin kullanımına ilişkin olarak bu yükümlülügün AİHS’ne uygunluğuna dair bir karar vermemiştir. Guild elektronik kelepçenin kullanılması yoluyla elektronik izlemenin AİHS m. 3, m. 5 ve m. 8 bakımından sorun yaratabileceğine dikkat çekmektedir ${ }^{120}$. Öncelikle elektronik kelepçe özellikle sürekli ve uzun süreli kullanıldığında kişiye fiziki zarar verebilmekte (ağrı, yara veya geçmeyen kelepçe izine neden olabilmekte) ve kişinin psikolojik durumunu ciddi şekilde olumsuz etkileyebilmektedir. Yazara göre elektronik izlemenin söz konusu olumsuz etkileri AİHS m. 3 uyarınca onur kırıcı veya aşağılayıcı muamele olarak kabul edilebilir ve elektronik izleme tedbiri bu nedenle AİHS m.3’ün ihlalini doğurabilecek niteliktedir ${ }^{121}$. İkinci olarak, özellikle ev hapsi gibi kısıtlayıcı tedbirler ile birlikte uygulandığında elektronik izleme idari gözetime alternatif bir tedbir olmaktan çıkıp idari gözetimin bir çeşidi haline gelmektedir ${ }^{122}$. Bu da elektronik izlemenin kişilerin özgürlük ve güvenlik hakkını ciddi anlamda kısıtlaması anlamına gelecek ve bu tedbirin AİHS m. 5’e uygunluğunun değerlendirilmesi zorunluluğu ortaya çıkacaktır ${ }^{123}$. Bu değerlendirmede idarenin elektronik izlemenin gerekli, makul ve orantılı olduğunu kanıtlama zorunluluğu söz konusu olacaktır. Üçüncü olarak, elektronik izleme ile edinilen veriler insan hakları hukukuna uygun şekilde işlenmeli, saklanmalı veya korunmalıdır. Bunun aksi AİHS m. 8 ile korunan özel ve aile hayatına saygı hakkına hukuka aykırı bir müdahale teşkil edebilecektir ${ }^{124}$. Yine elektronik kelepçenin kullanılması kişinin normal hayatına devam etmesine izin vermez ve aile hayatına ciddi şekilde zarar verir ise bu da AİHS $\mathrm{m}$. 8 bakımından birtakım sorunlar yaratabilecektir.

Elektronik izlemenin özelikle elektronik kelepçenin kullanıldığı durumların kişilerin psikolojisi üzerindeki olumsuz etkileri ve özellikle kişi özgürlüğü ve güvenliği hakkı, özel ve aile hayatına saygı hakkı ile insani olmayan veya aşağılayıcı muamele yasağına olan ciddi müdahalesi göz önüne alındığında elektronik izlemenin diğer alternatiflere göre son çare olarak kullanılması gerekmektedir $^{125}$. Bu husus ışığında YUKK’a elektronik kelepçenin son çare olarak kullanılması ve

118 Sarah Campbell, Maria Baqueriza, James Ingram, Last Resort or First Resort: Immigration Detention of Children in the UK, BID and The Children's Society, 2011, s. 89-90; Bloomfield s. 41.

119 Alternatives to Immigration and Asylum Detention in the EU Time for Implementation, Philippe De Bruycker, Alice Bloomfield, Evangelia (Lilian) Tsourdi Joanna Pétin (Eds.) (2015) < https://odysseus-network.eu/wp-content/ uploads/2015/02/FINAL-REPORT-Alternatives-to-detention-in-the-EU.pdf> erişim tarihi: 10 Mayıs 2020, s.103.

120 Elspeth Guild'in argümanları için ibid, s. 102, 103.

121 ibid, s. 102, 103.

122 European Migration Network (EMN), The use of detention and alternatives to detention in the context of immigration policies Synthesis Report, 2014, s. 36.

123 Alternatives to Immigration and Asylum Detention in the EU Time for Implementation, Philippe De Bruycker, Alice Bloomfield, Evangelia (Lilian) Tsourdi Joanna Pétin (Eds.) (2015) < https://odysseus-network.eu/wp-content/ uploads/2015/02/FINAL-REPORT-Alternatives-to-detention-in-the-EU.pdf> erişim tarihi: 10 Mayıs 2020, s. 102, 103.

124 ibid, s. 102, 103.

125 ibid, s. 103. 
hassas durumdaki yabancılar hakkında elektronik kelepçe tedbirinin uygulanmaması gerektiğine dair bir hüküm getirilmesinin yerinde olacağ 1 görüşündeyiz ${ }^{126}$.

\section{5. İdari Gözetim Altına Alınan Yabancıların Elektronik ve İletişim Cihazları İncelenebileceğine ilişskin Değişikliğin Değerlendirilmesi}

\section{A. IIIgili Kanun Değişikliği}

6/12/2019 tarihli ve 7196 sayılı Kanunun 78. maddesiyle, YUKK m. 57’ye eklenen 8. fikra ile idari gözetim altına alınan yabancıların uyruklarının tespit edilmesi amacıyla elektronik ve iletişim cihazları incelenebileceği ve bu inceleme sonucunda elde edilen verilerin bu amaç dışında kullanılamayacağı düzenlenmiştir.

\section{B. IIgili AiHM Kararları}

AİHS m. 8(1) "Herkes özel ve aile hayatına, konutuna ve yazışmasına saygı gösterilmesi hakkına sahiptir" hükmünü içermektedir. AİHS m. 8(2) ise bu hakkın ancak bir kamu makamının müdahalesi ile ve ancak müdahalenin yasayla öngörülmüş ve demokratik bir toplumda ulusal güvenlik, kamu güvenliği, ülkenin ekonomik refahı, düzenin korunması, suç işlenmesinin önlenmesi, sağlığın veya ahlakın veya başkalarının hak ve özgürlüklerinin korunması için gerekli bir tedbir olması durumunda kısıtlanabileceğini düzenlemektedir. AİHM içtihadında yazışma (haberleşme), bireyin diğer kişilerle mektup, elektronik posta, telefon, internet, teleks ya da faks gibi araçlarla kurduğu iletişimi de kapsayacak şekilde geniş yorumlanmaktadır ${ }^{127}$. Haberleşmenin içeriğinin denetlenmesi, haberleşmenin gizliliğine ve dolayısıyla haberleşme özgürlüğüne yönelik ağır bir müdahale oluşturmaktadır ${ }^{128}$. YUKK değişikliğinde öngörülen yabancının uyruğunun tespiti amacıyla rızasına bakılmaksızın elektronik ve iletişim cihazlarına el konulup incelenebileceği hükmü kişinin özel hayatına ve haberleşme hakkına önemli bir kısıtlama getirmektedir. Bu da söz konusu hükmün AİHS m. 8’e uygunluğunun tartışılmasını gerekli kılmaktadır.

AİHS m. 8’e uygun sayılması için haberleşme özgürlügüne yapılan bir müdahalenin öncelikle kanunla öngörülmesi gerekmektedir ${ }^{129}$. Bunun yanı sıra, müdahalenin yasal dayanağını

126 Örneğin Birleşik Krallık İçişleri tarafından yayınlanan Kılavuzda elektronik kelepçe tedbirinin çocuklar, hamile ve yeni doğum yapmış kadınlar, yaşllar, daha önce işkence görmüş kişiler ve psikolojik sorunları olan kişiler hakkında uygulanmaması gerektiği açıkça belirtilmiştir. United Kingdom Home Office, Immigration Bail Version 5.0, 2020, <https://assets.publishing.service.gov.uk/government/uploads/system/uploads/attachment_data/file/869352/ Immigration-bail-v5.0ext.pdf> erişim tarihi: 110 Mayıs 2020.

127 Niemietz v. Germany App no 13710/88 (ECHR, 16 December 1992) para 32; Copland v. UK App no 62617/00 (ECHR, 3 April 2007) para 41; Barbulescu v. Romania, [GC], App no 61496/08 (ECHR, 5 September 2017) para 72; G. Arslan Öncü, Özel Yaşama ve Aile Yaşamına Saygı Hakkı, Anayasa Mahkemesine Bireysel Başvuru El Kitapları Serisi - 8, 2019, s. 134; GÖZÜBÜYÜK, GÖLCÜKLÜ, SAYGILI, s. 332.

128 AYM, Ramazan Vural, (B. No: 2013/1148) 7/7/2015, para 33.

129 Silver and others v. UK IHRL 41 (ECHR 1983) para 85-90; Klass and others v. Germany App no 5029/71 (ECHR, 6 
oluşturan mevzuatın ulaşılabilir, yeterince açık ve belirli bir eylemin gerektirdiği sonuçlar açısından öngörülebilir olması ve söz konusu sınırlandırmanın da meşru bir amaca dayalı olması gerekmektedir ${ }^{130}$. Son olarak, hakka yapılan müdahale demokratik bir toplumda gerekli ve ölçülü olmalidır ${ }^{131}$.

Yukarıda da belirtildiği üzere haberleşme özgürlüğüne yapılan kısıtlamalar erişilebilir, açık, anlaşılabilir ve öngörülebilir bir kanuni dayanağa ve meşru bir amaca sahip olmalı, demokratik bir toplumda gerekli ve ölçülü (orantılı) olmalıdır ${ }^{132}$. Bunun yanı sıra, haberleşme özgürlügüne getirilebilecek keyfi müdahalelere karşı yeterli güvencelerin kanunda ve uygulamada yer alması gerekmektedir ${ }^{133}$. Eğer söz konusu kanuni dayanak haberleşme özgürlügüne müdahale konusunda idareye takdir yetkisi tanıyor ise bu yetkinin çerçevesinin kanunda açıkça belirtmesi gerekmektedir $^{134}$. AİHM Mehmet Nuri Özen ve diğerleri/Türkiye kararında, kanunun idari makamların haberleşme özgürlüğüne müdahalesine izin verdiği ve idareye takdir yetkisi tanıdığ 1 durumlarda ilgili kanunun bu yetkinin çerçevesini açıkça belirlemesi gerektiğine karar vermiştir ${ }^{135}$.

\section{Değerlendirme}

YUKK m. 57(8)'e getirilen hükümle idareye yabancıların haberleşme özgürlügünü kısıtlama yetkisi getirilmektedir, her ne kadar idarenin inceleme sonucunda elde edilen verileri bu amaç dişında kullanılamayacağı belirtilmişse de bu konudaki idarenin yetkisinin kapsamı, incelemenin tam olarak hangi fiilleri kapsayacağı, incelemenin ne kadar süreceği, bu yetkinin kötüye kullanılması durumunda başvurulacak herhangi bir idari veya hukuki başvuru yolu olup olmadığı madde metninde yer almamaktadır. ${ }^{136} \mathrm{Bu}$ nedenle işbu hükmün AİHM önündeki bir davaya konu olması durumunda, Mahkemenin bu düzenlemeyi açık, anlaşılabilir ve öngörülebilir olarak kabul etmesi olası değildir. Ayrıca söz konusu hak kısıtlamasının çoğunlukla herhangi bir suç işlememiş göçmenler için öngörülmesinin ölçülülük kıstasına uygunluğu da tartışmalıdır. YUKK m. 57(8)'de yer alan hüküm haberleşmenin gizliliğine müdahale içermekte fakat söz konusu müdahale için usulüne göre verilmiş hâkim kararı veya kanunla yetkili kılınmış merciin yazılı emrinin bulunması aranmamaktadır. Bu

October 1978) para 42-55; Campbell v.UK App no 3590/88 (25 March 1992) para 34; AYM, Ramazan Vural, (B. No: 2013/1148) 7/7/2015, para 34.

130 Silver and others v. UK IHRL 41 (ECHR 1983) para 85-90; Klass and others v. Germany App no 5029/71 (ECHR, 6 October 1978) para 42-55; Campbell v.UK App no 3590/88 (25 March 1992) para 34; AYM, Ramazan Vural, (B. No: 2013/1148) 7/7/2015, para 34.

131 Silver and others v. UK IHRL 41 (ECHR 1983) para 85-90; Klass and others v. Germany App no 5029/71 (ECHR, 6 October 1978) para 42-55; Campbell v.UK App no 3590/88 (25 March 1992) para 34; AYM, Ramazan Vural, (B. No: 2013/1148) 7/7/2015, para 34 .

132 ÖNCÜ, s. 147.

133 ibid, s. 147.

134 ibid, s. 139.

135 Mehmet Nuri Özen and others v. Turkey App no 15672/08 (ECHR, 11 January 2011) para 56.

136 Teksoy konuyla ilgili olarak şu değerlendirmeyi yapmıştır: "7196 sayılı Kanun ile getirilen yeni hüküm, yöntemin icrası için ayrıca özel bir karar verme usulünü düzenleme gereği görmediği gibi, bu yöntemin kimin tarafindan ve nasıl icra edileceğine ilişkin kurallar da içermemektedir.” TEKSOY, s. 19. 
nedenle ne şekilde uygulanacağına bağlı olarak bu değişikliğin AİHS m. 8’i ihlal edebilecek nitelikte olduğu görüşündeyiz ${ }^{137}$.

YUKK m. 57(8)'de yer alan bu hükmün insan haklarına uygunluğu ile ilgili yapılacak değerlendirmede dikkate alınması gereken bir başka husus da yabancının elektronik ve iletişim cihazlarında yer alan kayıtları arasında avukatları ile olan yazışmalarının yer alma ihtimalidir. AİHM avukatmüvekkil arasındaki haberleşmelerin denetlenmesinin AİHS m. 8 koruma altında olduğunu kabul etmektedir ${ }^{138}$. YUKK m. 57(8) uyarınca yapılacak incelemede, avukat-müvekkil arasındaki haberleşme özgürlüğünün ne şekilde korunacağ kanunda açık değildir. Bu da YUKK m. 57(8)'deki düzenlemenin AİHS m. 8’i ihlal etme olasılığını arttıran bir unsur olarak karşımıza çıkmaktadır.

\section{Sonuç}

Makalede 6/12/2019 tarihli ve 7196 sayılı Bazı Kanunlarda ve 375 Sayılı Kanun Hükmünde Kararnamede Değişiklik yapılmasına Dair Kanun ile 6458 Sayılı Yabancılar ve Uluslararası Koruma Kanunu’nda yapılan değişiklikler Avrupa İnsan Hakları Sözleşmesi ışı̆̆ında incelenmiş ve şu sonuçlara ulaşılmıştır. İlk olarak, sınır dışı kararlarına itiraz süresinin 15 günden yedi güne indirilmesi hakkında sınır dışı kararı verilen yabancıların özellikle idari gözetim altındaki kişilerin avukata, hukuki danışmanlığa ve adli yardıma erişebilmesi; Türk mevzuatı hakkında bilgi sahibi olması, Türkçe kapsamlı bir itiraz başvurusu hazırlayabilmesi ve başvuru için kanıtlayıcı belge temin edebilmesi için oldukça kısa bir süredir ve bu sürenin kısalığı gelecekte AİHS m. 3 bağlamında AİHS m. 13 ihlallerine neden olabilecek niteliktedir.

İkinci olarak, kanun değişikliği ile yabancının rızası saklı kalmak kaydıyla, dava açma süresi içinde veya yargı yoluna başvurulması hâlinde yargılama sonuçlanıncaya kadar yabancının sınır dışı edilemeyeceğini düzenlenmiştir. AİHM içtihadına göre bir yabancının sınır dışı edilmesi durumunda AİHS m. 2, AİHS m. 3 ve Ek Protokol No 4 m. 4'e aykırı bir muamele ile karşılaşacağına dair riskin varlığı söz konusu ise sınır dışı kararına itiraz başvurusunun otomatik olarak yürütmeyi durdurması gerekmektedir. Kısaca YUKK m. 53'de yapılan sınır dışı kararına itirazın doğrudan yürütmeyi durdurmasına ilişkin değişiklik AİHM içtihadı ile uyumludur.

Üçüncü olarak, YUKK m. 60/A ile düzenlenen gönüllü geri dönüş yardımı ve m. 57/A ile kanuna idari gözetime alternatif bir yükümlülük olarak getirilen geri dönüş danışmanlığının ilk bakışta AİHS’ne aykırılı̆̆ı söz konusu değildir. Yeter ki; bu programlar ve yardımlar kapsamında yabancıların geri dönüş kararını özgür iradesi ile bilinçli olarak vermesi sağlansın ve yabancılar hiçbir şekilde geri dönüşe zorlanmasın. Şunu da belirtmek gerekir ki; AİHM hakkında sınır dışı kararı bulunan bir yabancının ülkesine geri dönüşte gönüllü geri dönüş yardımından faydalanmasının veya

137 Anayasa m. 22 açıkça "usulüne göre verilmiş hâkim kararı olmadıkça ve gecikmesinde sakınca bulunan hallerde de kanunla yetkili kılınmış merciin yazılı emri bulunmadıkça haberleşme engellenemez ve gizliliğine dokunulamaz" hükmünü içermektedir. Söz konusu kanun değişikliği aynı zamanda değil aynı zamanda Anayasa m. 22'yi de ihlal edebilecek niteliktedir. Bkz. ayrıca TEKSOY, s. 37.

138 Schönenberger and Durmaz v. Switzerland App no 1136885 (ECHR, 20 June 1988); Campbell v. UK App no 13590/88, (ECHR, 25 March 1992). 
dönüşün kendi sorumluluğunda olduğuna dair bir belge imzalamasının devletin AİHS m. 2 ve m. 3 kapsamındaki sorumlulukları bakımından bir etkisi olmadığını kabul etmektedir.

Dördüncü olarak, YUKK m. 7'de yapılan değişiklik ile kabul edilemeyen yolcu kapsamındaki yabancıların havaalanlarındaki transit bölgeleri de dahil olmak üzere sınır kapılarında haklarındaki işlemler sonuçlanıncaya kadar bekletilmesi/tutulması öngörülse de kanunda söz konusu yabancıların transit bölgelerde bekletilebileceği azami süreye ilişkin açık bir hüküm yer almamaktadır. YUKK'da Türkiye'ye girişlerine izin verilmeyecek yabancıların sınır kapılarında tutulması ve bekletilmesi ile ilgili olarak idarenin yazılı ve gerekçeli bir karar vermesi gerekmemekte ve bu tutulma/bekletilmeye ilişkin gidilebilecek bir hukuk yolu yer almamaktadır. Bu hususlar özellikle Türkiye’ye girişine izin verilmeyecek yabancılar hakkında geri çevrilme ve/veya sınır dışı kararlarının ivedilikle alınmadığ ve yabancıların uzun süre sınır kapılarında avukata erişimleri olmadan bekletildiği durumlarda AİHS m. 5’i ihlal edebilecek niteliktedir. Bunun yanı sıra şunu da ifade etmek gerekir ki, sınır kapılarında uluslararası koruma talebinde bulunmak isteyen yabanciların ivedilikle uluslararası koruma prosedürlerine, avukata ve hukuki danışmanlığa erişiminin sağlanması büyük önem arz etmektedir. Son olarak, yabancıların sınır kapılarında bekletildiği/tutulduğu yerlere ilişkin koşulların AİHS m. 3'e uygun olması da Mahkeme tarafindan aranmaktadır.

Beşinci olarak, ilk bakışta kanuna yeni eklenen m. 57/A ile hukukumuza getirilen idari gözetime alternatif yükümlülüklerden bildirimde bulunma, belirli adreste ikamet etme, geri dönüş danışmanlı̆̆ 1 ve aile temelli geri dönüş AİHS'de yer alan haklara önemli bir kısıtlama getirmemektedir. Bununla birlikte kamu yararına hizmetlerde gönüllülük esasıyla görev alma, teminat ve elektronik kelepçenin kullanılması yoluyla elektronik izleme AİHS bakımından birtakım sorunlara yol açabilecek niteliktedir. Gelecekteki AİHS ihlallerini önlemek için söz konusu yükümlülüklerin ilgili güvenceleri de içerecek biçimde detaylı şekilde mevzuatta düzenlenmesi önerilmiştir. Özellikle elektronik kelepçenin keyfi ve uzun süreli kullanımının AİHS m. 3, 5 ve 8 bakımından bazı sorunlara yol açabileceği ve bunun önlenmesi için elektronik kelepçe tedbirinin ancak son çare olarak kullanılması gerektiği belirtilmiştir.

Son olarak YUKK m. 57'de yapılan yabanciların uyruklarının tespit edilmesi amaciyla elektronik ve iletişim cihazları incelenebileceğine dair değişikliğin uygulanması yabancıların haberleşme özgürlügünün kısıtlanması anlamına gelmektedir. Bu nedenle söz konusu kısıtlamanın AİHS m. 8'e uygun olmasi gerekmektedir. Ne var ki, YUKK m. 57'ye eklenen fikranın idarenin yabanciların haberleşme özgürlügünü kısıtlama yetkisine dair açık, anlaşlabilir ve öngörülebilir bir düzenleme olarak kabul edilmesi güçtür. Bunun yanı sıra, söz konusu fikrada yabancıların iletişim cihazlarında yer alan avukat-müvekkil gizliliği kapsamındaki yazışmalara ne şekilde saygı gösterileceği de açık değildir. Bu nedenle YUKK m. 57(8)'deki düzenlemenin AİHS m. 8’i ihlal etme olasılı̆̆ı mevcuttur.

\section{KAYNAKÇA}

Alternatives to Immigration and Asylum Detention in the EU Time for Implementation, De Bruycker P., Bloomfield A., Tsourdi L., Pétin J., (Eds.) (2015) <https://odysseus-network.eu/wp-content/uploads/2015/02/ FINAL-REPORT-Alternatives-to-detention-in-the-EU.pdf> erişim tarihi: 10 Mayıs 2020 
Antalya Barosu İnsan Hakları Merkezi, Dünya Evimiz Derneği, Uluslararası Dayanışma Derneği, Göç Araştırmaları Derneği (GAR), Göçmen Dayanışma Derneği, Hak İnisiyatifi Derneği, Halkların Dayanışma Köprüsü Derneği, İltica ve Göç Araştırmaları Derneği (İGAM), İnsan Hakları Derneği (İHD), İnsan Hakları Gündemi Derneği (İHGD), İzmir'de Suriyeli Mültecilerle Dayanışma Derneği, Kaos GL, Kırkayak Kültür, Medya ve Mülteci Hakları Derneği, Mültecilerle Dayanışma Derneği (Mültecider), Uluslararası Mülteci Hakları Derneği, Van Barosu, Yurttaşlık Derneği, Yuva Derneği, YUKK Değişiklikleri Hakkında Ortak Değerlendirme, 4 Aralık 2019 < https://www.gocarastirmalaridernegi. org/attachments/article/144/yukk-degisiklikleri-hakkinda-ortak-degerlendirme.pdf> erişim tarihi: 10 Mayıs 2020

Arslan Öncü G., Özel Yaşama ve Aile Yaşamına Saygı Hakkı, Anayasa Mahkemesine Bireysel Başvuru El Kitapları Serisi - 8, 2019

Avrupa İşkencenin ve İnsanlık dışı veya Onur kırıcı Muamelenin veya Cezanın Önlenmesi Komitesi (CPT), ‘Gözetim Altında Tutulan Yasa Dışı Göçmenler Bilgi Notu’ CPT/Inf(2017), 3 Mart 2019 < https:// rm.coe.int/1680727f8d > erişim tarihi: 10 Mayıs 2020

Bal A., 'Kölelik, Zorla Çalıştırma ve Benzer Uygulamalara İlişkin Yasağın Uluslararası Hukuk ve AİHM İçtihatları Çerçevesinde Gelişimi’ Yıldırım Beyazıt Hukuk Dergisi, 2019, 2: 55-112

Bloomfield A., 'Alternatives to detention at a crossroads: Humanisation or criminalisation?' Refugee Survey Quarterly, 2016, 35.1:29-46

Campbell S., Baqueriza M., Ingram J., Last Resort or First Resort: Immigration Detention of Children in the UK, BID and The Children's Society, 2011

Costello C., The Human Rights of Migrants in European Law, 1. Baskı, Oxford University Press, 2015

Committee on the Rights of the Child (CRC), Report of the 2012 Day of General Discussion on the Rights of All Children in the Context of International Migration, 28 September 2012, <https://www.refworld.org/ docid/51 efb6fa4.html> erişim tarihi: 10 Mayıs 2020

Costello C. and Kaytaz E., 'Building empirical research into alternatives to detention: perceptions of asylumseekers and refugees in Toronto and Geneva', UNHCR, 2013

Council of Europe Steering Committee for Human Rights (CDDH), 'Analysis of the Legal and Practical Aspects of Effective Alternatives to Detention in the Context of Migration', CDDH(2017)R88add2, 26 Ocak 2018

Crisp J., Long K., 'Safe and Voluntary Refugee Repatriation: From Principle to Practice' Journal on Migration and Human Security, 2016, 4.3:141-147

Doğan İ. (Editör) Avrupa İnsan Hakları Sözleşmesi Hukuku, 1. Baskı, Astana Yayınları, 2019

ECHR Fact Sheet, 'Unaccompanied migrant minors in detention' Haziran 2019, < https://www.echr.coe.int/ Documents/FS_Unaccompanied_migrant_minors_detention_ENG.pdf > erişim tarihi: 10 Mayıs 2020

ECHR, Guide on the case-law of the European Convention on Human Rights Immigration, Updated on 30 April 2020, <https://www.echr.coe.int/Documents/Guide_ Immigration_ENG.pdf?utm_source=flexmail \&utm_medium=e-mail \&utm_ campaign=nieuwsbriefvreemdelingenrechteninternationalfamilierecht $2020 \mathrm{nr} 4 \& \mathrm{utm}_{-}$ content=guide+on+case+law++immigration + update $+30+$ april $+2020 \mathrm{Z}>$ erişim tarihi: 10 Mayıs 2020

Ekşi N., 6458 Sayılı Yabancılar ve Uluslararası Koruma Kanunu’nda İdari Gözetim, 1. Baskı, Beta Yayınevi, 2014 Ekşi N., Yabancılar ve Uluslararası Koruma Hukuku, 4. Baskı, Beta Yayınevi, 2017

European Migration Network (EMN), The use of detention and alternatives to detention in the context of immigration policies Synthesis Report, 2014, <https://ec.europa.eu/home-affairs/sites/homeaffairs/ files/what-we-do/networks/european_migration_network/reports/docs/emn-studies/emn_study_ detention_alternatives_to_detention_synthesis_report_en.pdf > erişim tarihi: 10 Mayıs 2020 
Göçmen İ., Avrupa İnsan Hakları Sözleşmesi Işı̆̆ında Avrupa Birliği ve Türkiye Göç Hukuku, 1. Baskı, Seçkin, 2015

Gözübüyük Ş., Gölcüklü F., Saygılı A., Avrupa İnsan Hakları Sözleşmesi ve Uygulaması, 12. Baskı, Turhan Kitapevi, 2019

Harris D., O’Boyle M., Bates E. and Buckley C., Harris, O’Boyle \& Warbrick: Law of the European Convention on Human Rights 3. Bask1, Oxford University Press, 2014

Hathaway J. C., The Right of Refugees under International Law, Cambridge University Press, 2005

Ineli-Ciger M., 'Remedies Available against Asylum Decisions and Deportation Orders in Turkey: An Assessment in View of European Law and the European Convention on Human Rights' Nordic Journal of International Law, 2019, 88:216-249

İçduygu A., Ayaşlı E., 'Geri Dönüş Siyaseti: Suriyeli Mültecilerin Dönüş Göçü İhtimali ve Gelecek Senaryoları' MiReKoç Çalışma Notları, 2019 Nisan <https://mirekoc.ku.edu.tr/wp-content/uploads/2019/05/ Mirekoc_Makale_GeriDonusSiyaseti.pdf > erişim tarihi: 10 Mayıs 2020

İneli Ciğer M., 'Uluslararası Hukuk ve Karşılaştırmalı Hukukta İdari Gözetime Alternatif Tedbirler' Public and Private International Law Bulletin, 2020, 40.2: 809 - 839.

Mowbray A., Cases, Materials, and Commentary on the European Convention on Human Rights, 3. Bask1, Oxford University Press, 2012

Özkan I., 'Adil Yargılanma Hakkının Uluslararası Özel Hukuka Etkisi, Dokuz Eylül Hukuk Fakültesi Dergisi, Prof. Dr. Şeref Ertaş’a Armağan, 2017, 19:1767-1834

Özkan, I., Göç ve Sı̆̆ınma Hukuku, 3. Baskı, Seçkin, 2018

Reneman M., 'Speedy asylum procedures in the EU: Striking a fair balance between the need to process asylum cases efficiently and the asylum applicant's EU right to an effective remedy' International Journal of Refugee Law, 2013, 25.4:717-748

Report of the Special Rapporteur on the Human Rights of Migrants, François Crépeau, 2 April 2012, A/ $\mathrm{HRC} / 20 / 24$

Şirin T., Özgürlük ve Güvenlik Hakkı, Anayasa Mahkemesine Bireysel Başvuru Hakkı Serisi-1, MRK Baskı, 2018

Teksoy B., 'İdari Gözetim Altına Alınan Yabancıların Elektronik ve İletişim Cihazlarının İncelenmesine İlişkin Hükmün Değerlendirilmesi', Ankara Üniversitesi SBF Dergisi, 2020, 75.2: 517-556.

Tezcan D., Erdem M. R., Sancakdar O., Önok R. M., İnsan Hakları: El Kitabı, 8. Baskı, Seçkin, 2018.

Uluslararası Mülteci Hakları Derneği, 6458 Sayılı Yabancılar ve Uluslararası Koruma Kanunu’nda Değişiklik Yapılmasına Dair Kanun Taslağı İncelemesi, Kasım 2019 < https://www.umhd.org.tr/wp-content/ uploads/2019/11/kanun-tasla\%C4\%9F\%C4\%B1-incelemesi.pdf> erişim tarihi: 10 Mayıs 2020

UNHCR, Guidelines on the Applicable Criteria and Standards relating to the Detention of Asylum-Seekers and Alternatives to Detention, 2012 < https://www.refworld.org/docid/503489533b8.html > erişim tarihi: 10 Mayis 2020

UNHCR-OHCHR, Global Roundtable on Alternatives to Detention of Asylum-seekers, Refugees, Migrants and Stateless Persons, Summary Conclusions, Geneva, $2011<$ https://www.ohchr.org/Documents/Issues/ Migration/Events/SummaryConclusions.pdf> erişim tarihi: 10 Mayıs 2020 